\title{
Technical Note: The effects of five different defaunation methods on biogeochemical properties of intertidal sediment
}

\author{
T. J. Tolhurst ${ }^{1}{ }^{*}$, M. G. Chapman ${ }^{1}$, A. J. Underwood ${ }^{1}$, and J. J. Cruz ${ }^{1,2}$ \\ ${ }^{1}$ Centre for Research on Ecological Impacts of Coastal Cities, Marine Ecology Laboratories A11, University of Sydney, \\ NSW 2006, Australia \\ ${ }^{2}$ Instituto de Recursos Naturales Renovables, Universidad Simon Bolivar, Sartenejas, Baruta, Apartado Postal 89000, \\ Caracas, Venezuela \\ * current address: School of Environmental Sciences, University of East Anglia, Norwich Research Park, Norwich, \\ NR4 7TJ, UK
}

Correspondence to: T. J. Tolhurst (t.tolhurst@uea.ac.uk)

Received: 19 December 2011 - Published in Biogeosciences Discuss.: 31 January 2012

Revised: 7 August 2012 - Accepted: 8 August 2012 - Published: 24 September 2012

\begin{abstract}
Various methods have been used to remove organisms from sediments to investigate structure and function of faunal assemblages in intertidal habitats. Nevertheless, little is known about how these treatments affect properties of the sediments themselves, although changing these properties may cause changes in the assemblages, independently of other hypotheses being tested. This study assesses the efficacy of defaunation and effect on selected biogeochemical properties of five different methods of defaunating soft muddy sediments in an estuary. The methods were removal and freezing of sediment, removal and oven-heating, freezing in situ with liquid $\mathrm{N}_{2}$, spraying with formalin and spraying with hydrogen peroxide. The first four of these methods have been used in previous studies, whilst the fifth was considered to be a potentially useful defaunator because it does not leave toxic residues. The first two methods required sediment to be brought back to the lab, disrupting the natural structure of the sediment; the last three were done in situ, with much less disturbance.

Variables measured to assess effects of the treatments on the sediment were amount of water, grain size, total carbohydrate, suspension index (relative erosion rate), erosion threshold, chlorophyll $a$ and $b$, colloidal carbohydrate, $F_{\mathrm{o}}$ (minimal fluorescence) and $F_{\mathrm{v}} / F_{\mathrm{m}}$ (photosynthetic yield). There were no significant effects of any treatment on the first four variables. For the others, effects of defaunation varied from treatment to treatment and with time after treatment. Generally, the greatest disturbance was to the micro-
\end{abstract}

phytobenthos (MPB, measured by chlorophyll and fluorescence) and related variables. For most treatments, recovery was rapid, but the effects of formalin and $\mathrm{H}_{2} \mathrm{O}_{2}$ persisted for a few days. Effects on physical properties of the sediment were mostly minor and insignificant. Removal and freezing or heating, however, caused major changes to the sediments because of the disturbances involved. Choosing the appropriate method of defaunation is very important if interpretations are not to be confounded between the effects of defaunation per se and any effects of changes to other biota (such as microphytobenthos) and/or the properties of sediments caused by the method used to defaunate experimental areas.

\section{Introduction}

Intertidal areas, such as salt marshes, mangrove forests and mudflats, support diverse assemblages of organisms, many of which are intimately associated with the sediments (reviewed by Lopez and Levington, 1987). Biota alter the properties of and processes in sediments (Black et al., 2002), which have important consequences for associated fauna. Many organisms inhabiting sediment secrete extra-cellular polymeric substances (EPS), which are particularly effective stabilising agents, altering cohesion and erodibility of the sediment (Dade et al., 1990; Decho, 1990; Tolhurst et al., 2002; de Brouwer et al., 2005). Bioturbation by animals, e.g. burrowing and feeding, can significantly alter properties 
of sediments, such as erodibility, porosity, permeability and grain size (Meadows and Tait, 1989; Meadows et al., 1990). Erosion on mudflats is mediated by the interplay between biological and physical processes (de Brouwer et al., 2000; Defew et al., 2002; Tolhurst et al., 2006b) and can be significantly altered by fauna (Austen et al., 1999; Widdows et al., 2000; Andersen et al., 2002) and flora (Friend et al., 2003; Tolhurst et al., 2006a). Often, an organism can have multiple synergistic or antagonistic influences on properties and processes that may vary temporally and/or spatially (e.g. Fernandes et al., 2006).

Equally important are the responses of organisms to different properties of the sediment. For example, bioturbation may be reduced in areas with increased amounts of food (Taghon and Green, 1990); patterns of distribution may vary with sediment grain size (Snelgrove and Butman, 1994; Thrush et al., 2003) or algae on the substratum (Chapman and Tolhurst, 2004), and settlement may be enhanced by chemical cues from the substratum (Fitt and Coon, 1992). Thus, macrobenthos and other biota play a critical and complex role in the dynamics of intertidal sediments (Montserrat et al., 2008).

This intimate association between biological, physical and biogeochemical properties of sediments results in a highly complex system, making understanding the structure and functioning of intertidal sediments difficult (Gray, 1974; Lopez and Levinton, 1987; Woodin et al., 1995; Black et al., 2002; Chapman et al., 2010). Manipulative experiments of the fauna, flora or their habitats offer a robust framework for improving understanding of these habitats. One area where manipulative experiments are used is studying the role of fauna in mediating sediment properties and/or microphytobenthos and vice versa. Such experiments often require defaunation or removal of the animals from the sediment. For example, one may need to remove some or all of the organisms from sediments to assess the effects of disturbances on rates or methods of recovery (Levin, 1984; Negrello Filho et al., 2006; Van Colen et al., 2008; Norkko et al., 2010), on the strength of biological interactions (Thrush et al., 1992; Lohrer et al., 2010), or on functions such as nutrient fluxes (Biles et al., 2002; Lohrer et al., 2010) and erosion processes (de Deckere et al., 2001).

Previous studies in intertidal soft sediments have used a variety of different approaches to defaunate sediments (Table 1). There is no standardised methodology to defaunation; even within a given approach, different approaches are often combined (Table 1). The efficacy of these methods in killing fauna can be implicitly tested within the experiment (by comparison to control treatments; Thrush et al., 1996), or is assumed by the treatment (Levin, 1984). If the aim is to recreate a natural defaunation event, then the methodology not only needs to recreate a similar defaunation, but also recreate any effects the natural event has on other biota and the properties of the sediment. This is because of the intimate links between fauna, the properties of sediment and other biota, such as mi- crophytobenthos (Thrush et al., 2006; Hewitt et al., 2008). If one wants to disentangle the response of microphytobenthos from that of macrofauna during recovery from a disturbance that has modified both these variables, then experiments need to have a disturbance applied to natural sediment, a disturbance followed by defaunation and all possible procedural controls.

Due to the connection between organisms and sediments, care needs to be taken when manipulating one component, such as fauna, that other components are not unintentionally altered. Despite this, effects of defaunation on microphytobenthos and the properties of the sediments are rarely considered (although see Thrush et al., 1996; de Deckere et al., 2001; Slocum and Plante, 2006; Montserrat et al., 2008; Van Colen et al., 2008).

Our understanding of how different defaunation methods change the properties of the sediments and other biota remains poor. Any method of defaunation that alters properties of sediments may potentially alter post-treatment migration, settlement and recovery of not only fauna, but other biota because of responses to the changed sediment, rather than because of direct effects of defaunation. Changes to the properties of sediments (including its physical integrity) can also affect various other properties and processes (such as nutrient dynamics, erodibility etc.), which may potentially alter other properties and processes (either directly or indirectly) and, in turn, the biota. Therefore, choosing the appropriate method of defaunation is very important if interpretations are not to be confounded between the effects of defaunation per se and any effects of changes in properties of sediments and/or changes to other biota caused by the method used to defaunate experimental areas. For example, physical disturbance of the sediment during defaunation could directly alter properties and/or processes, which should not be erroneously attributed to the fauna.

Ultimately, the most appropriate method of defaunation will depend on the particular hypotheses being tested. For many experiments, the best method will be the one that removes all the fauna (or a specific subset of the fauna), whilst minimising impacts on sediments and other biota. There will, however, also be experiments where the main requirement is to minimise the effects on one or more specific properties of the sediment or to remove specific components of the biota, such as the microphytobenthos. For example, removing animals to test hypotheses about the effects of bioturbation on grain size requires a method of defaunation that minimises changes to grain size at the start of the experiment. Experiments investigating the effects of fauna on erodibility of sediments would require effects on the microphytobenthos (MPB) and sediments to be minimised.

The time scale over which different defaunating techniques operate is also important. To maintain defaunated patches for some period, a persistent defaunator may be appropriate. Alternatively, a non-persistent defaunator would 
Table 1. Summary of some of the various different approaches used to defaunate sediments; there is no standard methodology even when the same technique is used.

\begin{tabular}{|c|c|}
\hline Reference & Method \\
\hline Levin, 1984 & Air-dried \\
\hline Whitlatch and Zajac, 1985 & Air-dried 1 week \\
\hline Wu and Shinn, 1997 & Air-dried 1 month \\
\hline Lee, 1999 & Air-dried for several weeks \\
\hline $\mathrm{Lu}$ and $\mathrm{Wu}, 2000$ & Air-drying 1 month \\
\hline Sevidge and Taghon, 1988 & Sieved $300 \mu \mathrm{m}$, frozen \\
\hline Chandler and Fleeger, 1983 & Repeatedly frozen $\left(-20^{\circ} \mathrm{C}\right) 3$ or more times \\
\hline Thrush and Roper, 1988 & Frozen 10 days \\
\hline Berge, 1990 & Frozen \\
\hline Olafsson and Moore, 1990 & Large animals picked out and frozen \\
\hline Pechenick and Cerulli, 1991 & Sieved, frozen \\
\hline Thrush et al., 1992 & Sieved $2 \mathrm{~mm}$ and frozen \\
\hline Olafsson and Moore, 1992 & Frozen \\
\hline Snelgrove et al., 1992 & Frozen and freshwater \\
\hline Turner et al., 1997 & Frozen \\
\hline Hall and Frid, 1997 & Frozen $-18^{\circ} \mathrm{C}$ for $48 \mathrm{~h}$ \\
\hline Hsieh and Hsu, 1999 & Frozen $-70^{\circ} \mathrm{C}$ for 7 days (twice), mixed \\
\hline Ford et al., 1999 & Frozen at $18^{\circ} \mathrm{C}$ for $12 \mathrm{~h}$ \\
\hline Kline and Stekoll, 2001 & $\begin{array}{l}\text { Frozen } 1 \text { week }-20^{\circ} \mathrm{C}, 1 \text { week room temperature, washed with freshwater and salt water, re- } \\
\text { frigeration at } 4^{\circ} \mathrm{C} \text { for } 6 \text { weeks, Frozen } 0^{\circ} \mathrm{C} 1 \text { day }\end{array}$ \\
\hline Bolam and Fernandes, 2002 & Frozen-refrozen 6 times $-20^{\circ} \mathrm{C}$ \\
\hline Flemer et al., 2002 & Frozen and air-dried \\
\hline Hansen and Kristensen, 1997 & $\begin{array}{l}\text { Overlying water purged with } \mathrm{N}_{2} \text {, inducing anoxia that kills the animals or forces them up. } \\
\text { Restored to original condition with } \mathrm{O}_{2}\end{array}$ \\
\hline Gilbert et al., 1996 & $\mathrm{~N}_{2}$ method \\
\hline Heilskov and Holmer, 2001 & $\mathrm{~N}_{2}$ method \\
\hline Thrush et al., 1996 & Covered with black plastic and concrete slabs for 3 weeks \\
\hline Beukema et al., 1999 & Cover with synthetic material for 3 months \\
\hline Gamenick et al., 1996 & Covered with PVC foil 1 month. \\
\hline Stocks and Grossle, 2001 & Sediment enclosed in plastic bags for 2 to 3 weeks \\
\hline Gallagher et al., 1983 & Commercially purchased sand. \\
\hline Bostrom and Bonsdorff, 2000 & Commercially purchased sand \\
\hline Fegley, 1988 & Washed with distilled water and equal \# of dryings at $50^{\circ} \mathrm{C}$ in an oven \\
\hline Kern, 1990 & Baked at $200^{\circ} \mathrm{C}$ for $3 \mathrm{~h}$ \\
\hline Zhou, 2001 & Combustion at $500^{\circ} \mathrm{C}$ for $6 \mathrm{~h}$ \\
\hline Sandnes et al., 2000 & $30 \% \mathrm{NaCl}$ solution \\
\hline Hansen and Blackburn, 1991 & Anoxia. Corers sealed for $24 \mathrm{~h}$, macrofauna migrated up and removed \\
\hline Christensen et al., 2000 & Sieving (only removal of macrofauna) \\
\hline Service and Bell, 1987 & Moving a rake over the area for $20 \mathrm{~min}$ \\
\hline Crowe at al., 1987 & Immersion in freshwater 5 days, homogenised \\
\hline Negrello Filho et al., 2006 & $30 \mathrm{ml}$ of $40 \%$ formalin added to cores in situ \\
\hline Montserrat et al., 2008 & Covered with polyethylene sheet for 40 days \\
\hline Van Colen et al., 2008 & Covered with polyethylene sheet for 40 days \\
\hline
\end{tabular}

be more appropriate to study processes immediately after defaunation.

Given the interconnected nature of processes controlling properties of sediments, making a decision about the appropriate method is difficult. To be able to make informed decisions, more information is required on the effects of different defaunation methods on the properties of sediments as well as other biota. This study tested the effects of five dif- ferent methods of defaunation (with appropriate procedural controls for disturbance) on selected sedimentary properties and measures related to microphytobenthos over 15 days to identify any short-term changes caused by effects of the defaunation method itself. These included two common methods (removal and freezing or oven-heating; Table 1) that are assumed to cause complete defaunation but that also cause major disturbance to the physical integrity of the sediment. 
Three methods of treating sediment in situ were also tested, because they were expected to cause less disruption to the sediment. These were freezing with liquid $\mathrm{N}_{2}$ (which was expected to reproduce the defaunation effect of laboratory freezing) and poisoning with formalin (which has been used in previous studies) or hydrogen peroxide. In terms of persistence of treatments, formalin may leave toxic residues that persist in the sediment, but liquid $\mathrm{N}_{2}$ rapidly evaporates and $\mathrm{H}_{2} \mathrm{O}_{2}$ breaks down into water and oxygen, and so would be expected to be non-persistent.

\section{Materials and methods}

\subsection{Study site}

The experiment was done on an intertidal mudflat at Tambourine Bay, in the upper reaches of Sydney Harbour over 15 days, from 23 October 2003 (day 0) to 27 October 2003 (day 4) to 7 November 2003 (day 15). These intertidal flats differ from European estuaries, in being dominated by filamentous green algae (Murphy et al., 2004, 2008). Details of the site and its location can be found in Chapman and Tolhurst (2007).

\subsection{Experimental design and defaunation treatments}

Twenty-seven $30 \mathrm{~cm} \times 30 \mathrm{~cm}$ plots, at least $5 \mathrm{~m}$ apart, were marked. Five days prior to setting up the experiment, sediment was collected from six randomly selected plots, by carefully removing it to a depth of $10 \mathrm{~cm}$ and taking it back to the laboratory. Three of these samples were each thoroughly mixed (keeping the sediment from each plot separate) before being placed in an oven at $120^{\circ} \mathrm{C}$. The other three were similarly mixed and frozen at $-80^{\circ} \mathrm{C}$. The samples were left for 5 days. On the day the experiment started, these samples were taken into the field and placed into the original six plots (after excavating any recently deposited sediment to a suitable depth); therefore, the introduced sediment was flush with the surroundings. There was no attempt to replace any sediment into the same plot from which it was removed.

The remaining 18 plots were allocated to six other treatments, including the procedural controls $(n=3$ per treatment). For treatments where the plots were poisoned in situ (i.e. using formalin or $\mathrm{H}_{2} \mathrm{O}_{2}$ ) or frozen in situ (using liquid $\mathrm{N}_{2}$ ), the plots were surrounded by a frame of metal pushed into the sediment to a depth of $\sim 1 \mathrm{~cm}$ to prevent spread of the treatment to surrounding mud. Three replicate plots were then sprayed with $300 \mathrm{ml}$ of $37 \%$ formalin or $300 \mathrm{ml}$ of $35 \%$ $v / v \mathrm{H}_{2} \mathrm{O}_{2}$, or 41 of liquid $\mathrm{N}_{2}$ was poured into the frame.

There were three procedural controls: (PC1) sediment collected from a plot and then replaced into each plot after approximately $1 \mathrm{~h}$ with minimal disturbance to the structure of the sediment; (PC2) sediment removed the day prior to the experiment, taken to the laboratory and mixed, but neither heated nor frozen and then replaced in the plots the day the experiment started; (PC3) plots surrounded with the metal frame and the surface of the mud sprayed with $300 \mathrm{ml}$ of estuarine water to wet, but not poison, the surface of the sediment. These provided controls for the major disturbances associated with the various treatments. Measurements were taken on the day the experiment started (day 0), a minimum of $20 \mathrm{~min}$ after treatment.

\subsection{Properties of the sediments}

The microphytobenthos were measured immediately prior to taking sediment cores using a Heinz Walz Pulse Amplitude Modulation fluorometer (PAM; Honeywill et al., 2002; Consalvey et al., 2005). The area was dark-adapted for $15 \mathrm{~min}$, and the $F_{\mathrm{o}}$ (minimal fluorescence, indication of biomass) and yield ( $F_{\mathrm{v}} / F_{\mathrm{m}}$, indication of "health") were measured.

Two replicate cores $\sim 2 \mathrm{~mm}$ depth were collected from each plot at each time of sampling using the contact-core technique (Honeywill et al., 2002). Surface cores were used because this is where the majority of the microphytobenthos are found and using deeper cores masks patterns in microphytobenthos (Kelly et al., 2001). Also, many invertebrates are known to respond to cues associated with the surface of the substratum when colonising different habitats (Fitt and Coon, 1992; Woodin et al., 1995; Hardege et al., 1998). The same plots were sampled at each time, so care was taken not to sample the same spot twice.

A suite of variables, including components of the microphytobenthos, that are routinely measured and which are generally considered important in the ecology and sedimentology of mudflats were examined from these contact core samples. These were amounts of water, grains $<63 \mu \mathrm{m}$ (i.e. the mud fraction) and grains $>63 \mu \mathrm{m}$ (i.e. the sand and coarser fraction), organic matter, chlorophyll $a$ and $b$, total and colloidal carbohydrates. These were all expressed per surface area to avoid problems associated with using measures expressed as contents (Perkins et al., 2003; Tolhurst et al., 2005; Tolhurst and Chapman, 2005) and because the exact volume of cores was not available to calculate concentrations.

In addition to measuring fluorescence using PAM, chlorophyll $a$ and $b$ were measured spectrophotometrically from a sub-sample of the contact core, using a dimethylformamide (DMF) extraction, following the equations of Porra et al. (1989).

Chlorophyll $a=12\left(A_{664}-A_{750}\right)-3.11\left(A_{647}-A_{750}\right)$
Chlorophyll $b=20.78\left(A_{647}-A_{750}\right)-4.88\left(A_{664}-A_{750}\right)$

where $A$ is the absorption at the specified wavelengths.

Colloidal carbohydrates (the water-soluble fraction) and total carbohydrates were measured from a sub-sample of the contact core, using the sulphuric acid-phenol Dubois assay (Dubois et al., 1956) as per methods outlined in Underwood et al. (1995) and expressed as glucose equivalents using a standard curve. Approximately $0.2 \mathrm{~g}$ of freeze-dried sample 
was used for the colloidal assay and $0.0025-0.005 \mathrm{~g}$ for the total carbohydrate assay.

Organic matter was measured by weighing, then ashing the remaining sediment from the contact core in a furnace at $450{ }^{\circ} \mathrm{C}$ to obtain the weight of burnt material; this allowed back calculating of the amount of organic matter in the original mass of the sample. The ashed sediment was then washed through a $63 \mu \mathrm{m}$ sieve; the sieve containing the sand was then freeze-dried and reweighed to determine the amount of sand $(>63 \mu \mathrm{m})$ and mud $(<63 \mu \mathrm{m})$ by mass. To maintain consistency in the data, these were also expressed per surface area.

A cohesive strength meter (CSM) was used to measure the erosion threshold and relative erosion rate $\left(S_{i}\right)$ of the sediment (Tolhurst et al., 1999; Vardy et al., 2007). These measures correlate well with measures of shear strength using a fall-cone apparatus (Watts et al., 2003). Two replicate CSM measures were taken in each plot at each time.

Approximately $20 \mathrm{~min}$ after the treatments were set up, the plots that were poisoned were sampled to test the efficacy of methods in killing fauna compared to three untreated control plots. The macrofauna were sampled using 11.5 -cm-diameter cores to a depth of $10 \mathrm{~cm}$. In the laboratory, samples were sieved carefully over a $500 \mu \mathrm{m}$ sieve without being preserved and then examined under the microscope on the same day. All macrofauna were counted and scored as living or dead (where possible). Because freezing and drying at high temperatures have been evaluated previously (see Table 1), it was assumed these methods would kill all organisms.

\subsection{Statistical analysis}

For analysis, the treatments were split into two groups: (1) those that physically disturbed the sediment (removal to the laboratory for freezing or heating), their procedural controls (PC1 and PC2) and the undisturbed treatment; (2) those treatments where liquid was sprayed onto the sediment (formalin, liquid $\mathrm{N}_{2}, \mathrm{H}_{2} \mathrm{O}_{2}$ ), $\mathrm{PC} 3$ and the undisturbed treatment. The same undisturbed plots were used to compare with each of these groups.

\section{Results}

\subsection{Efficacy of defaunation}

Taxa were analysed only if clearly identifiable as alive or dead. There were no living animals in the samples that had been treated with formalin, and all animals in the undisturbed treatment were alive. The mean proportions of live animals in plots treated with liquid $\mathrm{N}_{2}$ or $\mathrm{H}_{2} \mathrm{O}_{2}$ were 0.48 (SE 0.10; $n=6$ ) and 0.63 (SE 0.01), respectively. Therefore, the only in situ treatment to kill all fauna was formalin; the other methods killed approximately half to two-thirds of the fauna. The most susceptible fauna were small crustaceans (such as amphipods) and polychaetes, where $0-42 \%$ of these survived the different treatments. In contrast, very few nemerteans, bivalves or gastropods died.

To test whether liquid $\mathrm{N}_{2}$ or $\mathrm{H}_{2} \mathrm{O}_{2}$ killed different taxa pro rata or selectively, the numbers of animals remaining alive were compared with those in the undisturbed treatments using standardised counts (i.e. relative proportions of taxa in the different samples). Assemblages differed between the two treatments and between the treatments and the undisturbed control (PERMANOVA $=$ NPMANOVA in Anderson, 2001, $P<0.05$ ). Liquid $\mathrm{N}_{2}$ killed most taxa, but neither capitellid nor nephtyiid polychaetes. $\mathrm{H}_{2} \mathrm{O}_{2}$ had little effect on polychaetes and oligochaetes, mainly affecting insect larvae and crustaceans.

\subsection{Effects on sediments that were physically disturbed}

Using the freezer or oven necessitates removing sediment to the laboratory with associated disturbances to the structure of the sediment. Variables were therefore analysed for these two treatments with their appropriate controls: undisturbed sediment, PC1 (removing and replacing sediment) and PC2 (removing, mixing and replacing sediment).

The water content, mud and sand fractions, organic matter, total carbohydrates, chlorophyll $b$ and erosion rate of the sediments were not affected by any of the treatments (analyses of variance for each variable; differences among treatments were not significant, $P>0.10$ for each variable at each time). With the exception of erosion rate and total carbohydrate, mean values were consistent across treatments (illustrated for sand and chlorophyll $b$ in Fig. 1a and b, respectively), so these results were not attributable to any problems of lack of power (i.e. there were no trends that might have been detected as significant with more replication). Although not significant, erosion rate was increased in the oven and PC1 and PC2 treatments on day 0, and average total carbohydrate was considerably larger in the control than all other treatments on day 0 .

The erosion threshold was increased significantly by the freezing on day 0 (analyses of variance, $P<0.01$; SNK tests, $P<0.05$; Fig. 1c), but there was neither significant difference between the undisturbed sediment and that heated in the oven, nor with the procedural controls. The mean values for all treatments on day 15 were consistently large (compare days 0 and 4 with day 15 in Fig. 1c); these values are consistent, however, with results obtained from other estuaries (Tolhurst et al., 2006a) and at other times in these sites (Tolhurst et al., 2010).

Chlorophyll $a, F_{\mathrm{o}}$ and $F_{\mathrm{v}} / F_{\mathrm{m}}$ were all significantly reduced by defaunating sediment in the freezer or oven (analyses of variance, $P<0.01$; SNK tests, $P<0.05 ; F_{\mathrm{O}}$ and chlorophyll $a$ illustrated in Fig. 1). These variables were, however, also reduced in both procedural controls and there was no significant difference between the two experimental treatments and these controls. Any consequent interpretation of these variables or effects on fauna cannot therefore be 

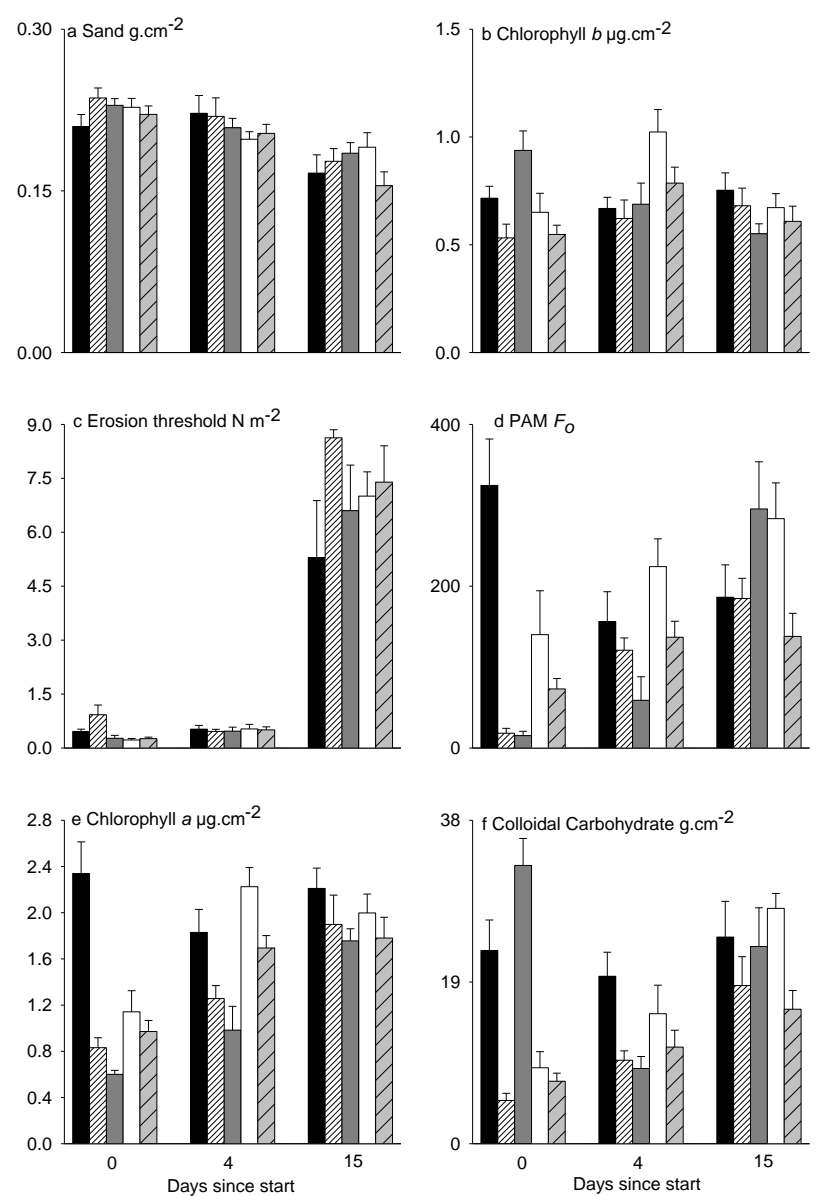

Fig. 1. Means (+ S.E., $n=3$ plots) of selected variables in treatments that were physically disturbed: black, undisturbed; fine stripe, frozen; grey, oven; white, PC2; coarse striped, PC1 (details in text).

attributed solely to defaunation, but rather to the disturbance of the sediment and microphytobenthos when the treatment plot is removed and later replaced.

Freezing the sediment significantly reduced amounts of colloidal carbohydrate, but to a similar degree as in the two procedural controls. Treating the sediment in the oven, in contrast, significantly increased amounts of colloidal carbohydrates (analyses of variance, $P<0.01$; SNK tests, $P<$ 0.05; means in Fig. 1f).

By day 4 and later, on day 15, there were no longer any significant differences in treatments from the undisturbed sediment or the procedural controls for $F_{\mathrm{o}}, F_{\mathrm{v}} / F_{\mathrm{m}}$ nor colloidal carbohydrates (Fig. 1d and f; analyses of variance, $P>0.10$ ), although $F_{\mathrm{o}}$ in the oven treatment was decreased compared to the other treatments on day 4 . In the freezer and oven treatments, the mean amounts of chlorophyll $a$ continued to be decreased compared with undisturbed treatment and controls on day 4, but measures had recovered and were no longer significantly different from controls by day 15 (analysis of variance; $P<0.01$; means in Fig. 1e).

\subsection{Effects on sediments treated in situ}

With the exception of $F_{\mathrm{v}} / F_{\mathrm{m}}$ on day 0 , which was significantly reduced, comparisons of the procedural control (PC3) with undisturbed sediment showed no significant differences (analyses of variance, SNK tests, all $P>0.10$; means in Fig. 2). Effects of treatments described below are therefore attributable to defaunation and not to any direct changes in the measured properties of sediments caused by the treatments. As for the disturbed sediments, there were no significant effects of any treatments on water content, the mud and sand fractions, organic matter, total carbohydrates, chlorophyll $b$ or erosion rate (analyses of variance, $P>0.10$; illustrated for chlorophyll $b$ in Fig. 2a), although average amounts of total carbohydrate were smaller in the liquid $\mathrm{N}_{2}, \mathrm{H}_{2} \mathrm{O}_{2}$ and procedural controls.

Application of $\mathrm{H}_{2} \mathrm{O}_{2}$ significantly reduced the mean amounts of chlorophyll $a, F_{\mathrm{o}}$ and $F_{\mathrm{v}} / F_{\mathrm{m}}$ compared with controls (Fig. 2b, c, d; analyses of variance, $P<0.01$; SNK tests, $P<0.05)$. These reductions persisted until day 4 (Fig. $2 \mathrm{~b}, \mathrm{c}$ ) except for $F_{\mathrm{v}} / F_{\mathrm{m}}$ which was no longer different from the undisturbed control (Fig. 2d). In contrast, mean amount of chlorophyll $b$ was significantly reduced on day 4 in the $\mathrm{H}_{2} \mathrm{O}_{2}$ treatment (analysis of variance, SNK tests, $P<0.01$; Fig 2a), but neither on day 0 nor 15 . Colloidal carbohydrate and erosion threshold were not affected by application of $\mathrm{H}_{2} \mathrm{O}_{2}$ at any time (analysis of variance, $P>0.10$, Fig. 2e and f).

Using formalin to defaunate sediments caused a significant increase in erosion threshold and colloidal carbohydrate on day 0 (Fig. 2e and f) and decreases in $F_{\mathrm{o}}$ and $F_{\mathrm{v}} / F_{\mathrm{m}}$ (Fig. 2c and d; analyses of variance and SNK tests for each variable, $P<0.01$ ). On day 4 , the reduced values of $F_{\mathrm{o}}$ and $F_{\mathrm{v}} / F_{\mathrm{m}}$ persisted and there were, now, reduced values of chlorophyll $a$ and $b$ and colloidal carbohydrates, despite colloidal carbohydrate having been increased on day 0 (means in Fig. 2; all analyses, $P<0.01$ ). Total carbohydrate was, on average, considerably less, but this difference was not significant. None of these effects persisted to day 15 , by which time no variables showed any significant differences from the controls (Fig. 2).

Liquid nitrogen was the second least effective treatment for killing the fauna (see above); it also had minimal effects upon the sediment properties. It only significantly influenced one variable in the sediments, reducing $F_{\mathrm{v}} / F_{\mathrm{m}}$ on day 0 (Fig. 2d; SNK test, $P<0.05$ ), but this reduction did not persist to day 4 (analyses of variance at days 4 and 15 showed no significant differences among treatments).

The figures only present an illustrative subset of the data; the full data set for all variables and treatments is given in Table 2. 
Table 2. Means and (SE) of the 12 variables for each treatment, for 0,4 and 15 days after treatment.

\begin{tabular}{|c|c|c|c|c|c|c|c|c|c|}
\hline Day 0 & Control & Frozen & Oven & PC1 & $\mathrm{PC} 2$ & Formalin & Liquid $\mathrm{N}_{2}$ & $\mathrm{H}_{2} \mathrm{O}_{2}$ & PC3 \\
\hline $\begin{array}{l}\text { Chlorophyll } a \\
\mu \mathrm{g} \mathrm{cm}^{-2}\end{array}$ & $\begin{array}{r}2.34 \\
(0.27)\end{array}$ & $\begin{array}{r}0.83 \\
(0.09)\end{array}$ & $\begin{array}{r}0.60 \\
(0.03)\end{array}$ & $\begin{array}{r}1.14 \\
(0.18)\end{array}$ & $\begin{array}{r}0.97 \\
(0.09)\end{array}$ & $\begin{array}{r}2.47 \\
(0.28)\end{array}$ & $\begin{array}{r}1.83 \\
(0.38)\end{array}$ & $\begin{array}{r}0.91 \\
(0.10)\end{array}$ & $\begin{array}{r}2.07 \\
(0.30)\end{array}$ \\
\hline $\begin{array}{l}\text { Chlorophyll } b \\
\mu \mathrm{g} \mathrm{cm}^{-2}\end{array}$ & $\begin{array}{r}0.72 \\
(0.06)\end{array}$ & $\begin{array}{r}0.53 \\
(0.06)\end{array}$ & $\begin{array}{r}0.94 \\
(0.09)\end{array}$ & $\begin{array}{r}0.65 \\
(0.09)\end{array}$ & $\begin{array}{r}0.55 \\
(0.04)\end{array}$ & $\begin{array}{r}0.67 \\
(0.07)\end{array}$ & $\begin{array}{r}0.55 \\
(0.09)\end{array}$ & $\begin{array}{r}0.57 \\
(0.05)\end{array}$ & $\begin{array}{r}0.61 \\
(0.08)\end{array}$ \\
\hline $\begin{array}{l}\text { Colloidal carbohydrate } \\
\mu \mathrm{g} \mathrm{cm}^{-2}\end{array}$ & $\begin{array}{l}22.70 \\
(3.59)\end{array}$ & $\begin{array}{r}5.07 \\
(0.84)\end{array}$ & $\begin{array}{l}32.68 \\
(3.18)\end{array}$ & $\begin{array}{r}8.93 \\
(1.88)\end{array}$ & $\begin{array}{r}7.34 \\
(0.95)\end{array}$ & $\begin{array}{r}52.00 \\
(10.04)\end{array}$ & $\begin{array}{r}17.76 \\
(3.68)\end{array}$ & $\begin{array}{l}30.66 \\
(5.47)\end{array}$ & $\begin{array}{r}22.33 \\
(5.51)\end{array}$ \\
\hline $\begin{array}{l}\text { Total Carbohydrate } \\
\mu \mathrm{g} \mathrm{cm}^{-2}\end{array}$ & $\begin{array}{r}1380 \\
(403)\end{array}$ & $\begin{array}{r}728 \\
(163)\end{array}$ & $\begin{array}{r}658 \\
(71)\end{array}$ & $\begin{array}{l}810 \\
(67)\end{array}$ & $\begin{array}{r}852 \\
(229)\end{array}$ & $\begin{array}{l}1159 \\
(287)\end{array}$ & $\begin{array}{l}621 \\
(99)\end{array}$ & $\begin{array}{r}660 \\
(178)\end{array}$ & $\begin{array}{r}801 \\
(171)\end{array}$ \\
\hline $\begin{array}{l}\text { Water } \\
\mathrm{mg} \mathrm{cm}^{-2}\end{array}$ & $\begin{array}{r}104.6 \\
(8.5)\end{array}$ & $\begin{array}{l}87.0 \\
(2.9)\end{array}$ & $\begin{array}{r}81.7 \\
(4.6)\end{array}$ & $\begin{array}{l}89.0 \\
(2.5)\end{array}$ & $\begin{array}{r}93.8 \\
(4.6)\end{array}$ & $\begin{array}{r}91.4 \\
(5.6)\end{array}$ & $\begin{array}{r}100.4 \\
(9.3)\end{array}$ & $\begin{array}{r}73.8 \\
(7.3)\end{array}$ & $\begin{array}{l}97.7 \\
(6.1)\end{array}$ \\
\hline $\begin{array}{l}\text { Organic matter } \\
\mathrm{mg} \mathrm{cm}^{-2}\end{array}$ & $\begin{array}{r}7.6 \\
(1.3)\end{array}$ & $\begin{array}{r}6.8 \\
(0.5)\end{array}$ & $\begin{array}{r}7.2 \\
(0.3)\end{array}$ & $\begin{array}{r}6.1 \\
(0.9)\end{array}$ & $\begin{array}{r}6.8 \\
(0.8)\end{array}$ & $\begin{array}{r}7.2 \\
(0.8)\end{array}$ & $\begin{array}{r}5.9 \\
(0.8)\end{array}$ & $\begin{array}{r}5.1 \\
(0.9)\end{array}$ & $\begin{array}{r}6.5 \\
(1.0)\end{array}$ \\
\hline $\begin{array}{l}\text { Sand } \\
\mathrm{mg} \mathrm{cm}\end{array}$ & $\begin{array}{r}209.7 \\
(11.2)\end{array}$ & $\begin{array}{r}236.1 \\
(9.3)\end{array}$ & $\begin{array}{r}229.3 \\
(6.1)\end{array}$ & $\begin{array}{r}227.5 \\
(8.2)\end{array}$ & $\begin{array}{r}221.0 \\
(7.8)\end{array}$ & $\begin{array}{l}211.2 \\
(11.0)\end{array}$ & $\begin{array}{l}207.9 \\
(20.3)\end{array}$ & $\begin{array}{r}212.2 \\
(4.3)\end{array}$ & $\begin{array}{r}232.2 \\
(3.7)\end{array}$ \\
\hline $\begin{array}{l}\text { Mud } \\
\mathrm{mg} \mathrm{cm}^{-2}\end{array}$ & $\begin{array}{l}38.6 \\
(6.2)\end{array}$ & $\begin{array}{l}26.6 \\
(3.4)\end{array}$ & $\begin{array}{l}28.0 \\
(1.4)\end{array}$ & $\begin{array}{l}26.1 \\
(2.5)\end{array}$ & $\begin{array}{l}28.9 \\
(2.9)\end{array}$ & $\begin{array}{r}29.7 \\
(3.8)\end{array}$ & $\begin{array}{l}25.9 \\
(3.9)\end{array}$ & $\begin{array}{l}21.9 \\
(3.5)\end{array}$ & $\begin{array}{l}31.1 \\
(4.5)\end{array}$ \\
\hline$F_{\mathrm{O}}$ & $\begin{array}{r}324.50 \\
(57.50)\end{array}$ & $\begin{array}{l}18.17 \\
(6.15)\end{array}$ & $\begin{array}{r}17.44 \\
(3.12)\end{array}$ & $\begin{array}{l}15.42 \\
(3.94)\end{array}$ & $\begin{array}{r}11.60 \\
(4.18)\end{array}$ & $\begin{array}{r}9.37 \\
(4.53)\end{array}$ & $\begin{array}{r}7.13 \\
(2.23)\end{array}$ & $\begin{array}{l}14.66 \\
(2.93)\end{array}$ & $\begin{array}{r}201.50 \\
(55.11)\end{array}$ \\
\hline Yield $F_{\mathrm{v}} / F_{\mathrm{m}}$ & $\begin{array}{r}(0.04) \\
0.54\end{array}$ & $\begin{array}{r}(0.17 \\
0.33\end{array}$ & $\begin{array}{r}(0.08) \\
0.27\end{array}$ & $\begin{array}{r}(0.04) \\
0.23\end{array}$ & $\begin{array}{r}(0.04) \\
0.26\end{array}$ & $\begin{array}{r}(0.25) \\
0.87\end{array}$ & $\begin{array}{r}(0.07) \\
0.33\end{array}$ & $\begin{array}{r}(0.08) \\
0.26\end{array}$ & $\begin{array}{r}(0.07) \\
0.30\end{array}$ \\
\hline Relative erosion rate $\left(S_{i}\right)$ & $\begin{array}{r}6.04 \\
(1.20)\end{array}$ & $\begin{array}{r}5.68 \\
(1.06)\end{array}$ & $\begin{array}{r}15.33 \\
(5.34)\end{array}$ & $\begin{array}{r}140.17 \\
(54.24)\end{array}$ & $\begin{array}{r}73.00 \\
(12.93)\end{array}$ & $\begin{array}{l}207.83 \\
(36.44)\end{array}$ & $\begin{array}{l}273.67 \\
(33.41)\end{array}$ & $\begin{array}{r}126.00 \\
(40.69)\end{array}$ & $\begin{array}{r}6.72 \\
(1.22)\end{array}$ \\
\hline $\begin{array}{l}\text { Erosion threshold } \\
\mathrm{Nm}^{-2}\end{array}$ & $\begin{array}{r}0.46 \\
(0.06\end{array}$ & $\begin{array}{r}0.92 \\
(0.27)\end{array}$ & $\begin{array}{r}0.25 \\
(0.17)\end{array}$ & $\begin{array}{r}0.38 \\
(0.03)\end{array}$ & $\begin{array}{r}0.24 \\
(0.09)\end{array}$ & $\begin{array}{r}0.06 \\
(0.02)\end{array}$ & $\begin{array}{r}0.12 \\
(0.07)\end{array}$ & $\begin{array}{r}0.03 \\
(0.02)\end{array}$ & $\begin{array}{r}0.46 \\
(0.09)\end{array}$ \\
\hline \multicolumn{10}{|l|}{ Day 4} \\
\hline $\begin{array}{l}\text { Chlorophyll- } a \\
\left(\mu \mathrm{g} \mathrm{cm}^{-2}\right)\end{array}$ & $\begin{array}{r}1.83 \\
(0.20)\end{array}$ & $\begin{array}{r}1.26 \\
(0.11)\end{array}$ & $\begin{array}{r}0.98 \\
(0.21)\end{array}$ & $\begin{array}{r}2.22 \\
(0.17)\end{array}$ & $\begin{array}{r}1.69 \\
(0.11)\end{array}$ & $\begin{array}{r}0.55 \\
(0.05)\end{array}$ & $\begin{array}{r}1.87 \\
(0.15)\end{array}$ & $\begin{array}{r}0.89 \\
(0.08)\end{array}$ & $\begin{array}{r}1.83 \\
(0.16)\end{array}$ \\
\hline $\begin{array}{l}\text { Chlorophyll- } b \\
\left(\mu \mathrm{g} \mathrm{cm}^{-2}\right)\end{array}$ & $\begin{array}{r}0.67 \\
(0.05)\end{array}$ & $\begin{array}{r}0.62 \\
(0.09)\end{array}$ & $\begin{array}{r}0.69 \\
(0.10)\end{array}$ & $\begin{array}{r}1.02 \\
(0.10)\end{array}$ & $\begin{array}{r}0.79 \\
(0.07)\end{array}$ & $\begin{array}{r}0.30 \\
(0.06)\end{array}$ & $\begin{array}{r}0.61 \\
(0.03)\end{array}$ & $\begin{array}{r}0.36 \\
(0.06)\end{array}$ & $\begin{array}{r}0.58 \\
(0.05)\end{array}$ \\
\hline $\begin{array}{l}\text { Colloidal carbohydrate } \\
\left(\mu \mathrm{g} \mathrm{cm}^{-2}\right)\end{array}$ & $\begin{array}{l}19.67 \\
(2.83)\end{array}$ & $\begin{array}{r}9.81 \\
(1.10)\end{array}$ & $\begin{array}{r}8.84 \\
(1.41)\end{array}$ & $\begin{array}{l}15.28 \\
(3.35)\end{array}$ & $\begin{array}{r}11.34 \\
(1.99)\end{array}$ & $\begin{array}{r}2.04 \\
(0.66)\end{array}$ & $\begin{array}{r}11.60 \\
(0.97)\end{array}$ & $\begin{array}{r}9.15 \\
(1.33)\end{array}$ & $\begin{array}{r}18.59 \\
(3.71)\end{array}$ \\
\hline $\begin{array}{l}\text { Total Carbohydrate } \\
\left(\mu \mathrm{g} \mathrm{cm}^{-2}\right)\end{array}$ & $\begin{array}{r}953 \\
(212)\end{array}$ & $\begin{array}{l}605 \\
(76)\end{array}$ & $\begin{array}{r}787 \\
(111)\end{array}$ & $\begin{array}{r}1098 \\
(186)\end{array}$ & $\begin{array}{r}819 \\
(166)\end{array}$ & $\begin{array}{r}203 \\
(50)\end{array}$ & $\begin{array}{r}802 \\
(300)\end{array}$ & $\begin{array}{r}510 \\
(190)\end{array}$ & $\begin{array}{r}578 \\
(156)\end{array}$ \\
\hline $\begin{array}{l}\text { Water } \\
\left(\mathrm{mg} \mathrm{cm}^{-2}\right)\end{array}$ & $\begin{array}{r}105.7 \\
(7.8)\end{array}$ & $\begin{array}{l}89.8 \\
(4.7)\end{array}$ & $\begin{array}{l}83.0 \\
(4.3)\end{array}$ & $\begin{array}{l}98.3 \\
(2.7)\end{array}$ & $\begin{array}{l}95.3 \\
(4.9)\end{array}$ & $\begin{array}{l}84.0 \\
(2.8)\end{array}$ & $\begin{array}{r}93.1 \\
(5.2)\end{array}$ & $\begin{array}{l}86.2 \\
(7.4)\end{array}$ & $\begin{array}{l}85.3 \\
(4.4)\end{array}$ \\
\hline $\begin{array}{l}\text { Organic matter } \\
\left(\mathrm{mg} \mathrm{cm}^{-2}\right)\end{array}$ & $\begin{array}{r}6.6 \\
(0.7)\end{array}$ & $\begin{array}{r}5.8 \\
(0.5)\end{array}$ & $\begin{array}{r}6.7 \\
(0.9)\end{array}$ & $\begin{array}{r}8.5 \\
(0.5)\end{array}$ & $\begin{array}{r}6.3 \\
(0.7)\end{array}$ & $\begin{array}{r}3.8 \\
(0.3)\end{array}$ & $\begin{array}{r}5.6 \\
(0.6)\end{array}$ & $\begin{array}{r}4.7 \\
(1.2)\end{array}$ & $\begin{array}{r}4.8 \\
(0.4)\end{array}$ \\
\hline $\begin{array}{l}\text { Sand } \\
\left(\mathrm{mg} \mathrm{cm}^{-2}\right)\end{array}$ & $\begin{array}{r}221.9 \\
(16.6)\end{array}$ & $\begin{array}{r}219.0 \\
(17.2)\end{array}$ & $\begin{array}{r}208.6 \\
(8.7)\end{array}$ & $\begin{array}{r}197.9 \\
(6.9)\end{array}$ & $\begin{array}{r}203.3 \\
(8.4)\end{array}$ & $\begin{array}{r}219.8 \\
(6.5)\end{array}$ & $\begin{array}{r}209.3 \\
(7.9)\end{array}$ & $\begin{array}{l}203.6 \\
(12.8)\end{array}$ & $\begin{array}{r}211.0 \\
(9.9)\end{array}$ \\
\hline $\begin{array}{l}\text { Mud } \\
\left(\mathrm{mg} \mathrm{cm}^{-2}\right)\end{array}$ & $\begin{array}{l}37.6 \\
(4.4)\end{array}$ & $\begin{array}{l}27.6 \\
(2.0)\end{array}$ & $\begin{array}{l}32.6 \\
(5.6)\end{array}$ & $\begin{array}{l}36.5 \\
(1.9)\end{array}$ & $\begin{array}{l}32.0 \\
(3.9)\end{array}$ & $\begin{array}{l}15.1 \\
(2.4)\end{array}$ & $\begin{array}{l}31.1 \\
(4.1)\end{array}$ & $\begin{array}{l}20.3 \\
(5.7)\end{array}$ & $\begin{array}{l}25.1 \\
(3.4)\end{array}$ \\
\hline$F_{\mathrm{O}}$ & $\begin{array}{l}156.33 \\
(36.86)\end{array}$ & $\begin{array}{l}120.83 \\
(15.23)\end{array}$ & $\begin{array}{r}59.00 \\
(29.01)\end{array}$ & $\begin{array}{l}224.17 \\
(34.43)\end{array}$ & $\begin{array}{l}137.00 \\
(19.62)\end{array}$ & $\begin{array}{r}4.67 \\
(3.22)\end{array}$ & $\begin{array}{l}231.33 \\
(21.74)\end{array}$ & $\begin{array}{r}55.50 \\
(13.30)\end{array}$ & $\begin{array}{l}305.66 \\
(64.21)\end{array}$ \\
\hline Yield $F_{\mathrm{v}} / F_{\mathrm{m}}$ & $\begin{array}{r}0.66 \\
(0.04)\end{array}$ & $\begin{array}{r}0.68 \\
(0.02)\end{array}$ & $\begin{array}{r}0.59 \\
(0.13)\end{array}$ & $\begin{array}{r}0.61 \\
(0.02)\end{array}$ & $\begin{array}{r}0.65 \\
(0.02)\end{array}$ & $\begin{array}{r}0.06 \\
(0.06)\end{array}$ & $\begin{array}{r}0.57 \\
(0.02)\end{array}$ & $\begin{array}{r}0.67 \\
(0.06)\end{array}$ & $\begin{array}{r}0.59 \\
(0.01)\end{array}$ \\
\hline $\begin{array}{l}\text { Relative erosion rate } \\
\left(S_{i}\right)\end{array}$ & $\begin{array}{r}6.63 \\
(1.87)\end{array}$ & $\begin{array}{r}11.20 \\
(3.32)\end{array}$ & $\begin{array}{l}10.60 \\
(2.75)\end{array}$ & $\begin{array}{r}5.35 \\
(1.32)\end{array}$ & $\begin{array}{r}7.07 \\
(2.03)\end{array}$ & $\begin{array}{r}19.51 \\
(4.44)\end{array}$ & $\begin{array}{r}7.92 \\
(2.79)\end{array}$ & $\begin{array}{r}14.66 \\
(4.11)\end{array}$ & $\begin{array}{r}5.38 \\
(0.59)\end{array}$ \\
\hline $\begin{array}{l}\text { Erosion threshold } \\
\left(\mathrm{Nm}^{-2}\right)\end{array}$ & $\begin{array}{r}0.52 \\
(0.11)\end{array}$ & $\begin{array}{r}0.46 \\
(0.06)\end{array}$ & $\begin{array}{r}0.47 \\
(0.11)\end{array}$ & $\begin{array}{r}0.53 \\
(0.13)\end{array}$ & $\begin{array}{r}0.51 \\
(0.08)\end{array}$ & $\begin{array}{r}0.35 \\
(0.10)\end{array}$ & $\begin{array}{r}0.64 \\
(0.08)\end{array}$ & $\begin{array}{r}0.42 \\
(0.07)\end{array}$ & $\begin{array}{r}0.47 \\
(0.07)\end{array}$ \\
\hline
\end{tabular}


Table 2. Continued.

\begin{tabular}{|c|c|c|c|c|c|c|c|c|c|}
\hline Day 15 & Control & Frozen & Oven & $\mathrm{PC} 1$ & $\mathrm{PC} 2$ & Formalin & Liquid $\mathrm{N}_{2}$ & $\mathrm{H}_{2} \mathrm{O}_{2}$ & PC3 \\
\hline $\begin{array}{l}\text { Chlorophyll- } a \\
\left(\mu \mathrm{g} \mathrm{cm}^{-2}\right)\end{array}$ & $\begin{array}{r}2.21 \\
(0.18)\end{array}$ & $\begin{array}{r}1.90 \\
(0.25)\end{array}$ & $\begin{array}{r}1.76 \\
(0.10)\end{array}$ & $\begin{array}{r}2.00 \\
(0.16)\end{array}$ & $\begin{array}{r}1.78 \\
(0.18)\end{array}$ & $\begin{array}{r}2.14 \\
(0.32)\end{array}$ & $\begin{array}{r}2.19 \\
(0.19)\end{array}$ & $\begin{array}{r}2.16 \\
(0.31)\end{array}$ & $\begin{array}{r}2.29 \\
(0.15)\end{array}$ \\
\hline $\begin{array}{l}\text { Chlorophyll- } b \\
\left(\mu \mathrm{g} \mathrm{cm}^{-2}\right)\end{array}$ & $\begin{array}{r}0.75 \\
(0.08)\end{array}$ & $\begin{array}{r}0.68 \\
(0.08)\end{array}$ & $\begin{array}{r}0.55 \\
(0.05)\end{array}$ & $\begin{array}{r}0.67 \\
(0.06)\end{array}$ & $\begin{array}{r}0.61 \\
(0.07)\end{array}$ & $\begin{array}{r}0.58 \\
(0.06)\end{array}$ & $\begin{array}{r}0.59 \\
(0.07)\end{array}$ & $\begin{array}{r}0.60 \\
(0.06)\end{array}$ & $\begin{array}{r}0.71 \\
(0.05)\end{array}$ \\
\hline $\begin{array}{l}\text { Colloidal carbohydrate } \\
\left(\mu \mathrm{g} \mathrm{cm}^{-2}\right)\end{array}$ & $\begin{array}{r}24.28 \\
(4.20)\end{array}$ & $\begin{array}{r}18.58 \\
(3.39)\end{array}$ & $\begin{array}{l}23.16 \\
(4.55)\end{array}$ & $\begin{array}{r}27.65 \\
(1.75)\end{array}$ & $\begin{array}{l}15.79 \\
(2.21)\end{array}$ & $\begin{array}{l}31.42 \\
(5.65)\end{array}$ & $\begin{array}{l}23.16 \\
(3.93)\end{array}$ & $\begin{array}{r}22.15 \\
(4.75)\end{array}$ & $\begin{array}{l}19.93 \\
(2.59)\end{array}$ \\
\hline $\begin{array}{l}\text { Total Carbohydrate } \\
\left(\mu \mathrm{g} \mathrm{cm}^{-2}\right)\end{array}$ & $\begin{array}{r}897 \\
(172)\end{array}$ & $\begin{array}{l}1022 \\
(127)\end{array}$ & $\begin{array}{r}727 \\
(59)\end{array}$ & $\begin{array}{r}1091 \\
(155)\end{array}$ & $\begin{array}{r}750 \\
(85)\end{array}$ & $\begin{array}{l}498 \\
(95)\end{array}$ & $\begin{array}{r}603 \\
(187)\end{array}$ & $\begin{array}{r}1010 \\
(188)\end{array}$ & $\begin{array}{r}994 \\
(199)\end{array}$ \\
\hline $\begin{array}{l}\text { Water } \\
\left(\mathrm{mg} \mathrm{cm}^{-2}\right)\end{array}$ & $\begin{array}{r}101.7 \\
(4.9)\end{array}$ & $\begin{array}{l}88.1 \\
(3.9)\end{array}$ & $\begin{array}{l}82.9 \\
(3.0)\end{array}$ & $\begin{array}{l}86.1 \\
(5.7)\end{array}$ & $\begin{array}{l}95.4 \\
(7.0)\end{array}$ & $\begin{array}{l}87.5 \\
(2.1)\end{array}$ & $\begin{array}{l}88.4 \\
(4.5)\end{array}$ & $\begin{array}{l}95.6 \\
(5.9)\end{array}$ & $\begin{array}{l}94.5 \\
(4.0)\end{array}$ \\
\hline $\begin{array}{l}\text { Organic matter } \\
\left(\mathrm{mg} \mathrm{cm}^{-2}\right)\end{array}$ & $\begin{array}{r}7.7 \\
(0.6)\end{array}$ & $\begin{array}{r}5.7 \\
(0.4)\end{array}$ & $\begin{array}{r}5.7 \\
(0.6)\end{array}$ & $\begin{array}{r}6.8 \\
(0.6)\end{array}$ & $\begin{array}{r}7.1 \\
(1.0)\end{array}$ & $\begin{array}{r}4.9 \\
(0.5)\end{array}$ & $\begin{array}{r}5.5 \\
(0.7)\end{array}$ & $\begin{array}{r}6.3 \\
(0.7)\end{array}$ & $\begin{array}{r}6.5 \\
(0.5)\end{array}$ \\
\hline $\begin{array}{l}\text { Sand } \\
\left(\mathrm{mg} \mathrm{cm}^{-2}\right)\end{array}$ & $\begin{array}{l}166.4 \\
(17.0)\end{array}$ & $\begin{array}{l}177.4 \\
(11.8)\end{array}$ & $\begin{array}{r}185.0 \\
(9.7)\end{array}$ & $\begin{array}{l}190.5 \\
(13.5)\end{array}$ & $\begin{array}{l}154.8 \\
(12.8)\end{array}$ & $\begin{array}{l}187.1 \\
(13.4)\end{array}$ & $\begin{array}{l}192.5 \\
(12.9)\end{array}$ & $\begin{array}{r}192.0 \\
(7.7)\end{array}$ & $\begin{array}{r}184.8 \\
(5.0)\end{array}$ \\
\hline $\begin{array}{l}\text { Mud } \\
\left(\mathrm{mg} \mathrm{cm}^{-2}\right)\end{array}$ & $\begin{array}{l}43.2 \\
(5.0)\end{array}$ & $\begin{array}{l}27.8 \\
(1.5)\end{array}$ & $\begin{array}{l}29.3 \\
(4.3)\end{array}$ & $\begin{array}{l}26.6 \\
(3.0)\end{array}$ & $\begin{array}{r}44.2 \\
(10.3)\end{array}$ & $\begin{array}{l}19.4 \\
(2.7)\end{array}$ & $\begin{array}{l}28.6 \\
(5.4)\end{array}$ & $\begin{array}{l}30.7 \\
(5.2)\end{array}$ & $\begin{array}{l}33.4 \\
(4.2)\end{array}$ \\
\hline$F_{\mathrm{O}}$ & $\begin{array}{l}186.33 \\
(40.00)\end{array}$ & $\begin{array}{l}184.83 \\
(24.82)\end{array}$ & $\begin{array}{r}295.50 \\
(58.29)\end{array}$ & $\begin{array}{l}283.50 \\
(44.24)\end{array}$ & $\begin{array}{l}138.00 \\
(28.52)\end{array}$ & $\begin{array}{l}498.50 \\
(48.82)\end{array}$ & $\begin{array}{l}285.00 \\
(39.70)\end{array}$ & $\begin{array}{l}243.17 \\
(54.57)\end{array}$ & $\begin{array}{r}278.33 \\
(31.87)\end{array}$ \\
\hline Yield $F_{\mathrm{v}} / F_{\mathrm{m}}$ & $\begin{array}{r}0.67 \\
(0.01)\end{array}$ & $\begin{array}{r}0.68 \\
(0.01)\end{array}$ & $\begin{array}{r}0.67 \\
(0.00)\end{array}$ & $\begin{array}{r}0.66 \\
(0.02)\end{array}$ & $\begin{array}{r}0.70 \\
(0.02)\end{array}$ & $\begin{array}{r}0.66 \\
(0.01)\end{array}$ & $\begin{array}{r}0.65 \\
(0.01)\end{array}$ & $\begin{array}{r}0.66 \\
(0.01)\end{array}$ & $\begin{array}{r}0.65 \\
(0.01)\end{array}$ \\
\hline $\begin{array}{l}\text { Relative erosion rate } \\
\left(S_{i}\right)\end{array}$ & $\begin{array}{r}1.04 \\
(0.41)\end{array}$ & $\begin{array}{r}0.19 \\
(0.05)\end{array}$ & $\begin{array}{r}7.32 \\
(6.94)\end{array}$ & $\begin{array}{r}0.40 \\
(0.07)\end{array}$ & $\begin{array}{r}0.31 \\
(0.10)\end{array}$ & $\begin{array}{r}2.70 \\
(1.97)\end{array}$ & $\begin{array}{r}1.31 \\
(0.70)\end{array}$ & $\begin{array}{r}0.31 \\
(0.13)\end{array}$ & $\begin{array}{r}0.20 \\
(0.07)\end{array}$ \\
\hline $\begin{array}{l}\text { Erosion threshold } \\
\left(\mathrm{Nm}^{-2}\right)\end{array}$ & $\begin{array}{r}5.30 \\
(1.58)\end{array}$ & $\begin{array}{r}8.63 \\
(0.23)\end{array}$ & $\begin{array}{r}6.60 \\
(1.27)\end{array}$ & $\begin{array}{r}7.01 \\
(0.68)\end{array}$ & $\begin{array}{r}7.40 \\
(1.01)\end{array}$ & $\begin{array}{r}5.19 \\
(1.53)\end{array}$ & $\begin{array}{r}5.71 \\
(1.68)\end{array}$ & $\begin{array}{r}7.89 \\
(0.63)\end{array}$ & $\begin{array}{r}7.61 \\
(0.52)\end{array}$ \\
\hline
\end{tabular}

\section{Discussion}

Because muddy sediments are complex and interactive systems, a change to one component of sediment is likely to have major impacts on other components. It is therefore necessary to determine what effect a defaunation method has not only on the biota, but on the properties of the sediment, so that interpretation of responses is not confounded by the effects of any abnormal conditions created in the sediment by the defaunation process. For example, Thistle (1981), Beukema (1995) and Beukema et al. (1999) noted that the abnormally large densities of infauna that developed in defaunated sediment immediately after deployment, which subsequently declined to background levels, could have been due to lack of competitors, or increased resources, but did not address whether the methods of defaunation changed these resources directly, rather than by the removal of animals. More recent studies have started to address this issue. For example, de Deckere et al. (2001) determined the effect of an insecticide on erosion threshold before using it in an experiment to investigate destabilisation of sediments by fauna, but did not consider its direct effects on microphytobenthos. Van Colen et al. (2008) and Montserrat et al. (2008) investigated the effects of using polyethylene sheet to defaunate sediments on selected properties of sediment and microphytobenthos, in relation to long-term recovery of macrobenthos and effects on sediment dynamics. The current study adds to this work by quantifying the initial effects on selected properties of sediments of five different methods for defaunating sediments.

\subsection{Treatments that physically disturbed the sediment}

Of the many methods that have been developed to defaunate sediment (Table 1), air-drying, freezing, or oven-heating are commonly used, yet this study shows that they can significantly alter some of the properties of the sediment. These methods also generally kill microphytobenthos in addition to fauna, making them unsuitable for experiments where the effects of microphytobenthos need to be isolated from the effects of fauna.

Here, freezing and oven-dried sediment were compared to undisturbed plots, in addition to sediment that had only been removed from the plots overnight and mixed, or removed and replaced in situ within an hour with minimal mixing. Whilst there were changes to some of the measured sediment properties, none of these treatments had significant impacts on any of the physical sedimentary components, i.e. amounts of water, or the mud or sand components. The sediment placed in the plots was saturated with water from 

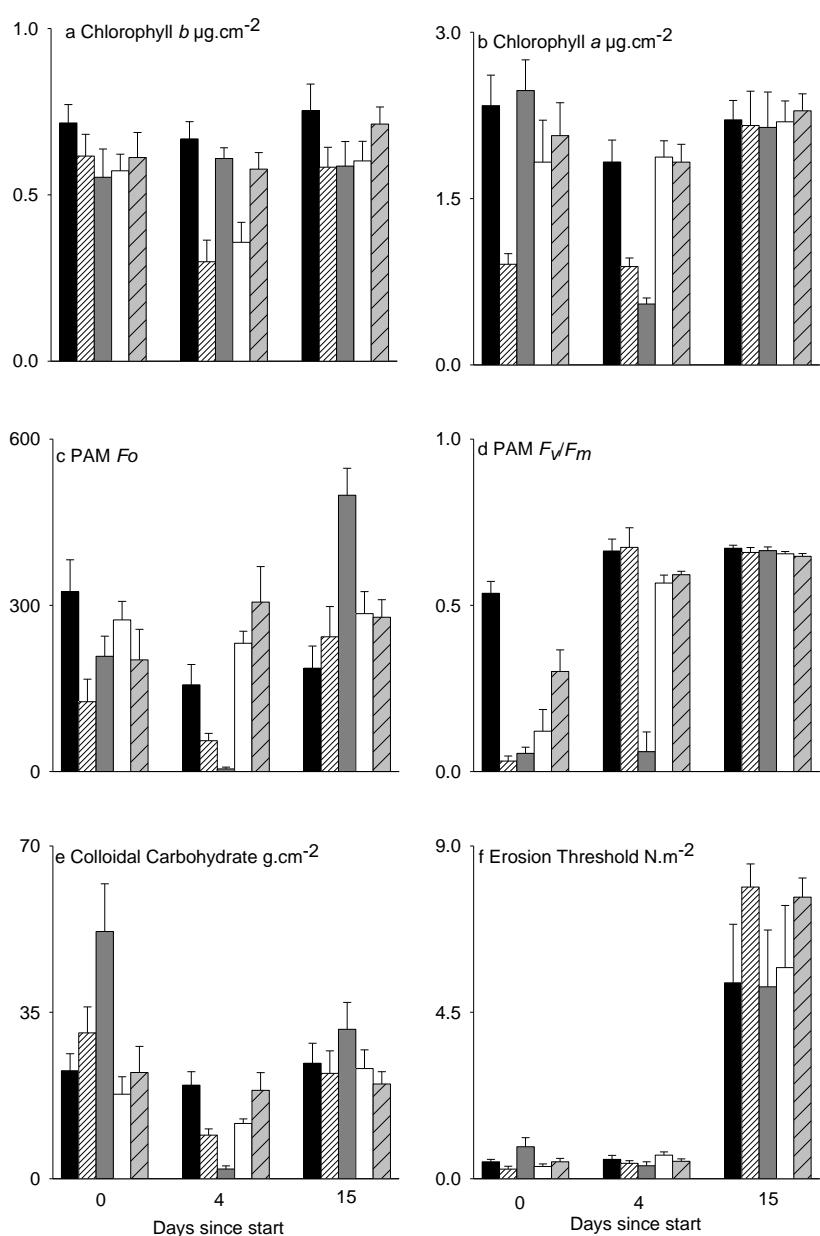

Fig. 2. Means (+ S.E., $n=3$ plots) of variables in sediments treated in situ: black, undisturbed; fine stripe, $\mathrm{H}_{2} \mathrm{O}_{2}$; grey, formalin; white, liquid $\mathrm{N}_{2}$; coarse stripe, $\mathrm{PC} 3$ (details in text).

the surrounding sediment soon after deployment, explaining the similarity in water content between the undisturbed sediment and the oven-dried sediment. All treatments reduced amounts of mud and increased sand on day 0 compared to the undisturbed control, although these changes were small and non-significant. This probably represents disturbance effects altering sediment structure, or mixing of coarser sediment from deeper in the plot into the surface $2 \mathrm{~mm}$ of sediment. Where stratification of grain size with depth is more pronounced, effects of experimental mixing would be expected to be greater.

There were slight decreases in organic matter in all treatments compared to the undisturbed control on day 0 . These decreases probably reflected the small decreases in mud (organic matter is often associated with fine sediment) and are quite likely also due to mixing. There were large decreases in total carbohydrates in all treatments compared to the undisturbed control, although there was a large amount of variability and these were not significant. This probably represents mixing of the carbohydrate found at the surface (associated with filamentous green algae) throughout the $10 \mathrm{~cm}$ depth of the treated sediment; this is supported by the reductions seen in the measures of algal biomass.

The major effects of these treatments were on the microphytobenthos on the surface of the sediment. This was shown as a decrease in chlorophyll $a$ (but not chlorophyll $b$ ) and the two PAM measures, $F_{\mathrm{o}}$ and $F_{\mathrm{v}} / F_{\mathrm{m}}$. Although one might expect freezing or heating to destroy microphytobenthos, this decrease was not significantly greater than that in the sediment that was simply disturbed and mixed. Because these microphytobenthos are most abundant in the top few $\mathrm{mm}$ of the sediment surface (Tolhurst, unpublished data), it is not surprising that mixing the sediment reduced the amount of chlorophyll measured on the surface. Where colonisation of fauna is influenced by amounts of microphytobenthos (Stocks and Grassle, 2001), treatments that mix the surface layers of the sediments into deeper sediment will potentially be confounded by the associated changes in the microphytobenthos. The disturbed sediment will not only have no (or fewer) fauna, but also less surface microphytobenthos. Although reduced, the amounts of chlorophyll $a$ measured chemically were not reduced to zero, even in the treatment that had been oven-dried for 4 days. This probably represents measurement of chlorophyll degradation products remaining after the experimental treatments, because the decline in fluorescence from the PAM (which measures the photosynthetic activity) was proportionally much greater.

Unlike diatom-dominated European estuaries, these habitats are dominated by filamentous green algae (Murphy et al., 2004,2008 ). Colonisation of treated plots by microphytobenthos was, however, relatively rapid, with recovery in many treatments after 4 days and recovery among all treatments by day 15. Previous work has shown that diatoms colonise defaunated sediments very rapidly, especially in the absence of grazers (Tolhurst et al., 2008a; Montserrat et al., 2008), and this study shows this to be true for other types of microphytobenthos. This suggests that, after 15 days, processes such as colonisation by fauna and erodibility would not be affected by changes to microphytobenthos. However, because earlier rates of faunal colonisation or erosion of sediments may have been altered by the changes in biomass of algae, the measured response in the defaunated sediment might have already been compromised. It is unknown if the species composition of the microphytobenthos was altered in any of our treatments, which may also affect colonisation by fauna and properties such as erodibility.

Freezing and oven-heating had different effects on other sedimentary properties. Freezing significantly increased the erosion threshold on day 0 . Although erosion rate was not altered, the cause of this is unknown, but may reflect the effects of freezing on the sediment structure. The oven treatment decreased erosion threshold and erosion rate, whilst freezing decreased colloidal carbohydrate, but similar changes occurred in the procedural controls, indicating these changes 
were caused by the physical disruption of the sediment fabric. Oven-heating also increased amounts of colloidal carbohydrate on day 0 , probably due to breakdown of dead biota. These effects had, however, disappeared by day 4, indicating that any effects on processes associated with changes to the erosion threshold of the sediment, or the amounts of colloidal carbohydrate, would be short-lived and have minimal influence on interpretation of experiments done over longer periods.

The short-term increase in amounts of colloidal carbohydrate in sediments heated in the oven or treated with formalin may have been due to the breakdown of insoluble carbohydrates and/or dead biota, possibly by bacteria and/or fungi. The rapid decline to ambient amounts within 4 days suggests rapid utilisation of this resource and redistribution into the food web as the sediments are recolonised. Similar rapid changes in colloidal carbohydrates have been found before in frozen sediments (Tolhurst et al., 2008a). This was not seen in the frozen treatment in this study, probably because the times of measurement after treatment were different. Further work is required to understand the cause(s) of these changes.

\subsection{Treatments where liquid was sprayed onto the sediment}

To assess methods of defaunation that cause less disturbance to the structure of the sediment, methods of defaunating the sediment in situ (formalin, liquid nitrogen and $\mathrm{H}_{2} \mathrm{O}_{2}$ ) were also evaluated. As predicted, changes to the physical properties in these treatments were minor and non-significant. Small decreases in mud in the treatments that sprayed waterbased solutions onto the sediment may have been due to physico-chemical dispersion, as the fresh water winnowed fine-grained sediment away, similar to some of the processes associated with rainfall (Tolhurst et al., 2006c, 2008b). As for the physically mixed treatments, changes in the organic matter mirrored the changes in the amount of mud.

Liquid $\mathrm{N}_{2}$ had very minor effects on the sediment, only reducing $F_{\mathrm{v}} / F_{\mathrm{m}}$, showing it could temporarily inhibit photosynthesis, but had no persistent effects, even on the microphytobenthos. Its defaunation effect was limited to the surface of the sediment, resulting in only partial defaunation; however, this may make it suitable for recreating certain pollution events that only affect the surface sediments. Chlorophyll $a$ and both measures of florescence using the PAM were considerably reduced by $\mathrm{H}_{2} \mathrm{O}_{2}$, highlighting its extreme toxicity and localised surface action. Effects on chlorophyll $a$ and $F_{\mathrm{o}}$ in this treatment persisted until day 4 , although $F_{\mathrm{v}} / F_{\mathrm{m}}$ had recovered, but these differences had disappeared by the day 15 . Formalin may have initially "fixed" the microphytobenthos, causing no change in biochemical chlorophyll and only a slight decrease in $F_{0}$, but a large decrease in the $F_{\mathrm{v}} / F_{\mathrm{m}}$ (a measure of photosynthetic activity), indicating the microphytobenthos was dead. Subsequently, all measures of microphytobenthos as well as both carbohydrates were re- duced in this treatment on day 4 , showing the effects of formalin to be more persistent than the $\mathrm{H}_{2} \mathrm{O}_{2}$ treatment. The reduction in carbohydrates is probably due to the lack of photosynthetic activity (as shown by the $F_{\mathrm{v}} / F_{\mathrm{m}}$ ) and reduction in fauna. Formalin also caused an increase in the erosion threshold and amounts of colloidal carbohydrate on day 0 . The increase in colloidal carbohydrate may be a result of secretion of EPS as a physiological response by the biota to poisoning. An increase in EPS would also explain the increased erosion threshold, as EPS stabilises sediment (Tolhurst et al., 2002; de Brouwer et al., 2005). Both these variables decreased by day 4 , reflecting the persistent nature of formalin in preventing growth of microphytobenthos. All of these effects had disappeared by the day 15 , again indicating that processes in sediments defaunated by these treatments may be confounded by changes to the sediments over the short term, but not after a week or so.

Because microphytobenthos are key to intertidal sediment properties and processes (Murphy and Tolhurst, 2009), they are intimately associated with the fauna, e.g. grazing decreasing microalgae (Daborn et al., 1993; Hillebrand et al., 2002), bioturbation and excretions of fauna releasing nutrients that may alter algal abundance (Dyson et al., 2007) etc. The fact that so many of the defaunation treatments used in this experiment reduced the amounts of algae is a concern. These data show there are consequences for interpretation of experiments that use these methods to test hypotheses about defaunation without considering the effects on microphytobenthos and to a lesser extent the biogeochemical properties of sediments. This is illustrated in simplified form in Fig. 3. The left-hand column illustrates some measure of a property of the sediment (e.g. amount of chlorophyll $a$, erodibility); the right-hand column is some variable associated with the fauna (e.g. the number of species present). At the time of the arrow on the x-axis, sediment is defaunated. In Fig. 3a, this is successful (the faunal measure becomes 0 ) and causes no changes to the sediment. The recovery of the fauna is complete when the dashed line recovers to the solid line representing control conditions. This can be interpreted in relation to experimental removal of previous fauna (i.e. all of the grey region is about responses to defaunation).

In Fig. 3b, defaunation was only partially successful and, again, caused no artefactual changes to the sediments. No hypothesis about defaunation can be tested, because changes in fauna (and related properties and processes) are in response to partial removal of unplanned amounts of unplanned components of the fauna. This is representative of the effects found for the liquid $\mathrm{N}_{2}$ treatment.

In Fig. 3c, defaunation is complete, but also alters properties of the sediment. This is representative of the oven, freezer and formalin treatments (the $\mathrm{H}_{2} \mathrm{O}_{2}$ treatment would be a combination of Fig. $3 \mathrm{~b}$ and c, causing partial defaunation and changes to sediments; this is not illustrated). Sediment recovers to natural conditions at the arrow above the line, where the dashed line meets control conditions. Prior to that 

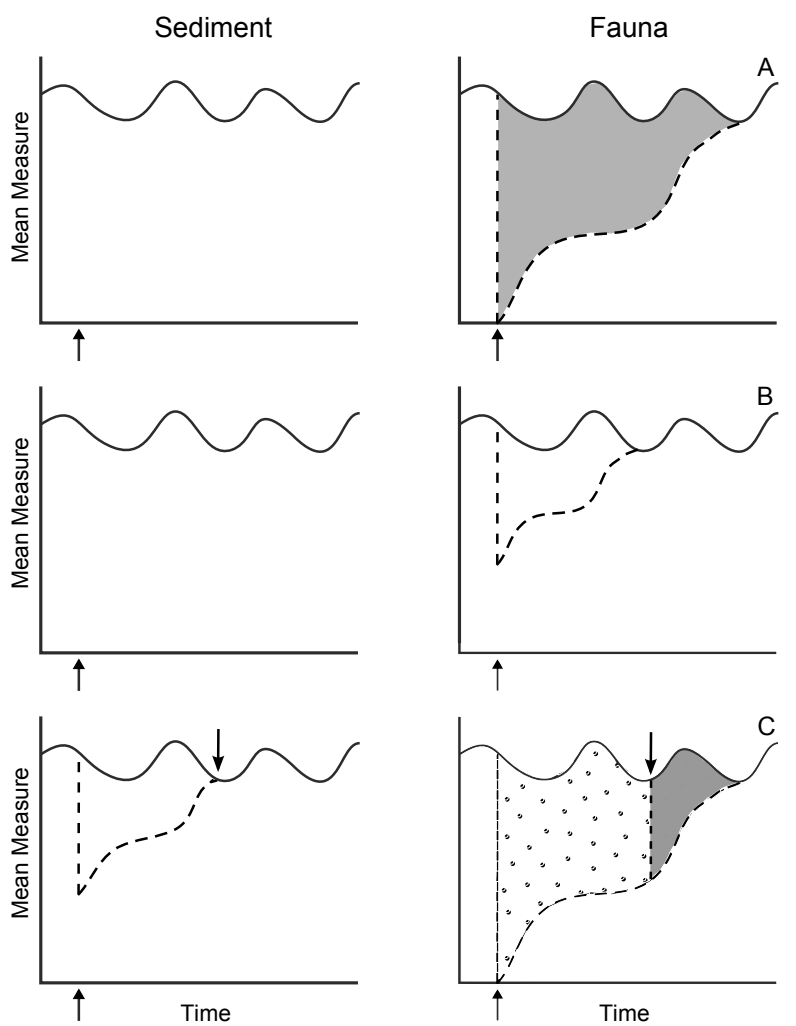

Fig. 3. Hypothetical patterns of responses of sediment and biota such as microphytobenthos (left-hand graphs) and fauna (right-hand graphs) to experimental defaunation at the time of the arrow on the $\mathrm{x}$-axis. Solid lines indicate unaltered, control conditions. Dashed lines indicate responses by sediment (including microphytobenthos) or fauna to experimental treatment. (A) Defaunation does not affect measures of properties of sediments; defaunation is complete and the grey area indicates that processes are in response to defaunation. (B) Defaunation is only partial, even though sediments and microphytobenthos are unaltered. No valid inferences can be made about effects of defaunation, because it is incomplete. (C) Defaunation is complete, but also alters sediments and microphytobenthos, which recover by the time shown by the upper arrows. Prior to this (the dotted region), fauna are responding to defaunation and simultaneous alteration of sediment and microphytobenthos. Subsequently, fauna are responding to influences of defaunation (grey region), but only if influences of altered sediment and microphytobenthos do not persist.

(the dotted region in the right-hand graph), responses by the fauna (and related properties and processes) must be interpreted in terms of the influences of defaunation and changed microphytobenthos and changed properties of the sediment. After the sediment recovers (the arrow above the line), it may be possible to interpret changes to the fauna (and related properties and processes) to be a response to defaunation because there are no further confounding influences of altered sediment or microphytobenthos. Whether or not this is a valid inference depends entirely on whether the influences of altered sediment, per se, on changes to fauna persist after the sediment has recovered. Persistent effects can occur, for example, if altering sediments alters cues for settlement of certain species, which then influence subsequent colonisation or survival and therefore patterns of recovery of other fauna. Without detailed experimental evidence about influences of early stage processes, such as colonisation of defaunated sediment where no alterations of properties of sediments had occurred, it would be very difficult, if not impossible, to make logically justifiable inferences.

When doing manipulative experiments to investigate processes such as erodibility, a defaunation method that minimises effects on microphytobenthos and sediment properties would be required. Because many natural processes that result in defaunation will also change other biota and properties of the sediment, the best defaunation methodology to investigate colonisation will be one that reproduces similar changes in these other biota and properties of the sediment.

\section{Conclusions}

Laboratory freezing and oven treatments significantly altered biogeochemical properties, physically disturbed the sediment and had persistent effects on biogeochemical properties; they are, however, excellent defaunators. Formalin had significant persistent effects on the sediment and microphytobenthos, but, because it was more effective at killing the fauna than was $\mathrm{H}_{2} \mathrm{O}_{2}$, it would be preferable if complete defaunation was required. Although liquid $\mathrm{N}_{2}$ had the least effect on the sediment and microphytobenthos, it was also not very effective at killing the fauna. Therefore, its positive aspect of minimal effect on the sediment is unlikely to outweigh the negative aspect of incomplete defaunation (presuming complete defaunation is the goal). Repeated or larger applications of liquid $\mathrm{N}_{2}$ do improve defaunation, but the freezing remains limited to $\sim 4 \mathrm{~cm}$ from the point of contact (R. Hale, personal communication, 2012). Thus, this method is only suitable for defaunation of the sediment surface, or use on small diameter cores that can be removed and submerged in liquid $\mathrm{N}_{2}$ to allow complete freezing. We consider $\mathrm{H}_{2} \mathrm{O}_{2}$ to be the least useful of the tested methodologies because of its poor defaunation and alteration of sediments and microphytobenthos.

Care is required in the interpretation of experiments that use currently available techniques for defaunation. Results must always be interpreted in terms of effects on other biota and the sediments, in addition to faunal processes influenced by defaunation itself. The results of this study will allow researchers to make more informed decisions about the methodology most appropriate for their research question. However, the effect of these defaunation methods on other biota (such as bacteria) and on biogeochemical properties not considered in this study still needs to be investigated, to provide a complete picture of what the most appropriate defaunation method is for any given experiment. 
Acknowledgements. This study was funded by the Australian Research Council through their Special Research Centre programme and an ARC Discovery Grant (DP0559073), the Centre for Research on Ecological Impacts of Coastal Cities and the University of Sydney. Many research support staff in the Centre, in particular C. Myers, assisted in the field and laboratory.

Edited by: J. Middelburg

\section{References}

Andersen, T. J., Jensen, K. T., Lund-Hansen, L., Mouritsen, K. N., and Pejrup, M.: Enhanced erodibility of fine-grained marine sediments by Hydrobia ulvae, J. Sea Res., 48, 51-58, 2002.

Anderson, M. J.: Permutation tests for univariate or multivariate analysis of variance and regression, Can. J. Fish. Aquat. Sci., 58, 626-639, 2001.

Austen, I., Andersen, T. J., and Edelvang, K.: The influence of benthic diatoms and invertebrates on the erodibility of an intertidal a mudflat, the Danish Wadden Sea, Estuar. Coast. Shelf S., 49, 99-111, 1999.

Berge, J. A.: Macrofauna recolonization of subtidal sediments experimentalstudies on defaunated sediment contaminated with crude-oil in 2 Norwegian fjords with unequal eutrophication status, 1. Community Responses, Mar. Ecol.-Prog. Ser., 66, 103115, doi:10.3354/meps066103, 1990.

Beukema, J. J.: Long-term effects of mechanical harvesting of lugworms Arenicola marina on the zoobenthic community of a tidal flat in the Wadden Sea, Neth. J. Sea Res., 33, 219-227, 1995.

Beukema, J. J., Flach, E. C., Dekker, R., and Starink, M.: A longterm study of the recovery of the macrozoobenthos on large defaunated plots on a tidal flat in the Wadden Sea, J. Sea Res., 42, 235-254, 1999.

Biles, C. L., Paterson, D. M., Ford, R. B., Solan, M., and Raffaelli, D. G.: Bioturbation, ecosystem functioning and community structure, Hydrol. Earth Syst. Sci., 6, 999-1005, doi:10.5194/hess-6-999-2002, 2002.

Black, K. S., Paterson, D. M., and Davidson, I. R.: Erosion of cuttings pile sediments: a laboratory flume study, Underwater Technol., 25, 51-59, 2002.

Bolam, S. G. and Fernandes, T. F.: The effects of macroalgal cover on the spatial distribution of macrobenthic invertebrates: the effect of macroalgal morphology, Hydrobiologia, 475, 437-448, 2002.

Bostrom, C. and Bonsdorff, E.: Zoobenthic community establishment and habitat complexity - the importance of seagrass shoot-density, morphology and physical disturbance for faunal recruitment, Mar. Ecol.-Prog. Ser., 205, 123-138, doi:10.3354/meps205123, 2000.

Chandler, G. T. and Fleeger, J. W.: Meiofaunal colonization of azoic estuarine sediment in Louisiana: Mechanisms of dispersal, J. Exp. Mar. Biol. Ecol., 69, 175-188, 1983.

Chapman, M. G. and Tolhurst, T. J.: The relationship between invertebrate assemblages and bio-dependent properties of sediment in urbanized temperate mangrove forests, J. Exp. Mar. Biol. Ecol., 304, 51-73, 2004.

Chapman, M. G. and Tolhurst, T. J.: Relationships between benthic macrofauna and biogeochemical properties of sediments at dif- ferent spatial scales and among different habitats in mangrove forests, J. Exp. Mar. Biol. Ecol., 343, 96-109, 2007.

Chapman, M. G., Tolhurst, T. J., Murphy, R. J., and Underwood, A. J.: Complex and inconsistent patterns of variation in benthos, micro-algae and sediment over multiple spatial scales, Mar. Ecol.-Prog. Ser., 398, 33-47, 2010.

Christensen, B., Vedel, A., and Kristensen, E.: Carbon and nitrogen fluxes in sediment inhabited by suspension-feeding (Nereis diversicolor) and non-suspension-feeding (N-virens) polychaetes, Mar. Ecol.-Prog. Ser., 192, 203-217, doi:10.3354/meps192203, 2000.

Consalvey, M., Perkins, R. G., Paterson, D. M., and Underwood, G. J. C.: Pam fluorescence: A beginners guide for benthic diatomists, Diatom Res., 20, 1-22, 2005.

Crowe, W. A., Josefson, A. J., and Svane, I.: Influence of adult density on recruitment into soft sediments: a short-term in situ sublittoral experiment Mar. Ecol.-Prog. Ser., 41, 61-69, 1987.

Daborn, G. R., Amos, C. L., Brylinsky, M., Christian, H., Drapeau, G., Faas, R. W., Grant, J., Long, B., Paterson, D. M., Perillo, G. M. E., and Piccolo, M. C.: An ecological cascade effect: migratory birds affect stability of intertidal sediments, Limnol. Oceanogr., 38, 225-231, 1993.

Dade, W. B., Davis, J. D., Nichols, P. D., Nowell, A. R. M., Thistle, D., Trexler, M. B., and White, D. C.: Effects of bacterial exopolymer adhesion on the entrainment of sand, Geomicrobiol. J., 8, 1-16, 1990 .

de Brouwer, J. F. C., Bjelic, S., de Deckere, E., and Stal, L. J.: Interplay between biology and sedimentology in a mudflat (Biezelingse Ham, Westerschelde, The Netherlands), Cont. Shelf Res., 20, 1159-1177, 2000.

de Brouwer, J. F. C., Wolfstein, K., Ruddy, G. K., Jones, T. E. R., and Stal, L. J.: Biogenic stabilization of intertidal sediments: the importance of extracellular polymeric substances produced by benthic diatoms, Microb. Ecol., 49, 501-512, 2005.

de Deckere, E., Tolhurst, T. J., and de Brouwer, J. F. C.: Destabilization of cohesive intertidal sediments by infauna, Estuar. Coast Shelf S., 53, 665-669, 2001.

Decho, A. W.: Microbial exopolymer secretions in ocean environments: their role(s) in food webs and marine processes, Annu. Rev. Oceanogr. Mar. Biol., 28, 73-153, 1990.

Defew, E. C., Tolhurst, T. J., and Paterson, D. M.: Site-specific features influence sediment stability of intertidal flats, Hydrol. Earth Syst. Sci., 6, 971-982, doi:10.5194/hess-6-971-2002, 2002.

Dubois, M., Gilles, K. A., Hamilton, J. K., Rebers, P. A., and Smith, F.: Colorimetric method for determination of sugars and related substances, Anal. Chem., 28, 350-356, 1956.

Dyson, K. E., Bulling, M. T., Solan, M., Hernandez-Milian, G., Raffaelli, D. G., White, P. C. L., and Paterson, D. M.: Influence of macrofaunal assemblages and environmental heterogeneity on microphytobenthic production in experimental systems, P. Roy. Soc. B-Biol. Sci., 274, 2547-2554, 2007.

Fegley, S. R.: A comparison of meiofaunal settlement onto the sediment surface and recolonization of defaunated sandy sediment, J. Exp. Mar. Biol. Ecol., 123, 97-113, 1988.

Fernandes, S., Sobral, P., and Costa, M. H.: Nereis diversicolor effect on the stability of cohesive intertidal sediments, Aquat. Ecol., 40, 567-579, 2006.

Fitt, W. K. and Coon, S. L.: Evidence for ammonia as a natural cue for recruitment of oyster larvae to oyster beds in a Georgia 
salt-marsh, Biol. Bull., 182, 401-408, 1992.

Flemer, D. A., Ruth, B. F., and Bundrick, C. M.: Effects of sediment type on macrobenthic infaunal colonization of laboratory microcosms, Hydrobiologia, 485, 83-96, 2002.

Ford, R. B., Thrush, S. F., and Probert, P. K.: Macrobenthic colonisation of disturbances on an intertidal sandflat: the influence of season and buried algae, Mar. Ecol.-Prog. Ser., 191, 163-174, doi:10.3354/meps 191163, 1999.

Friend, P. L., Ciavola, P., Cappucci, S., and Santos, R.: Biodependent bed parameters as a proxy tool for sediment stability in mixed habitat intertidal areas, Cont. Shelf Res., 23, 18991917, 2003.

Gallagher, E. D., Jumars, P. A., and Trueblood, D. D.: Facilitation of soft-bottom benthic succession by tube builders, Ecology, 64, 1200-1216, 1983.

Gamenick, I., Jahn, A., Vopel, K., and Giere, O.: Hypoxia and sulphide as structuring factors in a macrozoobenthic community on the Baltic Sea shore: Colonisation studies and tolerance experiments, Mar. Ecol.-Prog. Ser., 144, 73-85, doi:10.3354/meps 144073, 1996.

Gilbert, F., Stora, G., and Bertrand, J. C.: In situ bioturbation and hydrocarbon fate in an experimental contaminated Mediterranean coastal ecosystem, Chemosphere, 33, 1449-1458, 1996.

Gray, J. S.: Animal-sediment relationships, Annu. Rev. Oceanogr. Mar. Biol., 12, 223-261, 1974.

Hall, J. A. and Frid, C. L. J.: Colonisation patterns of adult macrobenthos in a polluted north sea estuary, Aquat. Ecol., 31, 333340, 1997.

Hansen, L. S. and Blackburn, T. H.: Aerobic and anaerobic mineralization of organic material in marine sediment microcosms, Mar. Ecol.-Prog. Ser., 75, 283-291, 1991.

Hansen, K. and Kristensen, E.: Impact of Macrofaunal Recolonization On Benthic Metabolism and Nutrient, Estuar. Coast. Shelf S., 45, 613-628, 1997.

Hardege, J. D., Bentley, M. G., and Snape, L.: Sediment selection by juvenile Arenicola marina, Mar. Ecol. Prog. Ser., 166, 187-195, 1998.

Heilskov, A. C. and Holmer, M.: Effects of benthic fauna on organic matter mineralization in fish-farm sediments: importance of size and abundance, ICES J. Mar. Sci./J. Conseil, 58, 427-434, 2001.

Hewitt, J. E., Thrush, S. F., and Dayton, P. D.: Habitat variation, species diversity and ecological functioning in a marine system, J. Exp. Mar. Biol. Ecol., 366, 116-122, 2008.

Hillebrand, H., Kahlert, M., Haglund, A. L., Berninger, U. G., Nagel, S., and Wickham, S.: Control of microbenthic communities by grazing and nutrient supply, Ecology, 83, 2205-2219, 2002.

Honeywill, C., Paterson, D. N., and Hagerthey, S. E.: Determination of microphytobenthic biomass using pulse-amplitude modulated minimum fluorescence, Eur. J. Phycol., 37, 485-492, 2002.

Hsieh, H. L. and Hsu, C. F.: Differential recruitment of annelids onto tidal elevations in an estuarine, Mar. Ecol.-Prog. Ser., 177, 93-102, 1999.

Kelly, J. A., Honeywill, C., and Paterson, D. M.: Microscale analysis of chlorophyll-a in cohesive, intertidal sediments: the implications of microphytobenthos distribution, J. Mar. Biol. Assoc. UK, 81, 151-162, 2001.

Kern, J. C.: Active and passive aspects of meiobenthic copepod dispersal at 2 sites near Mustang Island, Texas, Mar. Ecol.-Prog.
Ser., 60, 211-223, doi:10.3354/meps060211, 1990.

Kline, E. R. and Stekoll, M. S.: Colonization of mine tailings by marine invertebrates, Mar. Environ. Res., 51, 301-325, 2001.

Lee, S. Y.: The Effect of Mangrove Leaf Litter Enrichment on Macrobenthic Colonization of Defaunated Sandy Substrates, Estuar. Coast. Shelf S., 49, 703-712, 1999.

Levin, L. A.: Life-History and Dispersal Patterns in a Dense Infaunal Polychaete Assemblage - Community Structure and Response to Disturbance, Ecology, 65, 1185-1200, 1984.

Lopez, G. R. and Levinton, J. S.: Ecology of deposit-feeding animals in marine-sediments, Quart. Rev. Biol., 62, 235-260, 1987.

Lohrer, A. M., Halliday, N. J., Thrush, S. F., Hewitt, J. E., and Rodil, I. F.: Ecosystem functioning in a disturbance-recovery context: Contribution of macrofauna to primary production and nutrient release on intertidal sandflats, J. Exp. Mar. Biol. Ecol., 390, 6$13,2010$.

Lu, L. and Wu, R. S. S.: An experimental study on recolonization and succession of marine macrobenthos in defaunated sediment, Mar. Biol., 136, 291-302, 2000.

Meadows, P. S. and Tait, J.: Modification of sediment permeability and shear-strength by two burrowing invertebrates, Mar. Biol., 101, 75-82, 1989.

Meadows, P. S., Tait, J., and Hussain, S. A.: Effects of estuarine infauna on sediment stability and particle sedimentation, Hydrobiologia, 190, 263-266, 1990.

Montserrat, F., Van Colen, C., Degraer, S., Ysebaert, T., and Herman, P. M. J.: Benthic community-mediated sediment dynamics, Mar. Ecol.-Prog. Ser., 372, 43-59, 2008.

Murphy, R. J. and Tolhurst, T. J.: Effects of experimental manipulation of algae and fauna on the properties of intertidal soft sediments, J. Exp. Mar. Biol. Ecol., 379, 77-84, 2009.

Murphy, R. J., Tolhurst, T., Chapman, M. G., and Underwood, A. J.: Estimation of surface chlorophyll on an exposed mudflat using digital colour-infrared (CIR) photography, Estuar. Coast. Shelf S., 59, 625-638, 2004.

Murphy, R. J., Tolhurst, T. J., Chapman, M. G., and Underwood, A. J.: Spatial variation of chlorophyll on estuarine mudflats determined by field-based remote sensing, Mar. Ecol.-Prog. Ser., 365, 45-55, 2008.

Negrello Filho, O. A., Underwood, A. J., and Chapman, M. G.: Recolonization of infauna on a tidal flat: an experimental analysis of modes of dispersal, J. Exp. Mar. Biol. Ecol., 328, 240-250, 2006.

Norkko, J., Norkko, A., Thrush, S. F., Valanko, S., and Suurkuukka, H.: Conditional responses to increasing scales of disturbance, and potential implications for threshold dynamics in soft-sediment communities, Mar. Ecol.-Prog. Ser., 413, 253-266, 2010.

Olafsson, E. and Moore, C. G.: Control of meiobenthic abundance by macroepifauna in a subtidal muddy habitat, Mar. Ecol.-Prog. Ser., 65, 241-249, doi:10.3354/meps065241, 1990.

Olafsson, E. and Moore, C. G.: Effects of macroepifauna on developing nematode and harpacticoid assemblages in a subtidal muddy habitat, Mar. Ecol.-Prog. Ser., 84, 161-171, doi:10.3354/meps084161, 1992.

Pechenik, J. A. and Cerulli, T. R.: Influence of delayed metamorphosis on survival, growth, and reproduction of the marine polychaete Capitella sp. I, J. Exp. Mar. Biol. Ecol., 151, 17-27, 1991. 
Perkins, R. G., Honeywill, C., Consalvey, M., Austin, H. A., Tolhurst, T. J., and Paterson, D. M.: Changes in microphytobenthic chlorophyll $a$ and EPS resulting from sediment compaction due to de-watering: opposing patterns in concentration and content, Cont. Shelf Res., 23, 575-586, 2003.

Porra, R. J., Thompson, W. A., and Kriedemann, P. E.: Determination of accurate extinction coefficients and simultaneousequations for assaying chlorophyll- $a$ and chlorophyll- $b$ extracted with four different solvents: verification of the concentration of chlorophyll standards by atomic-absorption spectroscopy, Biochim. Biophys. Acta, 975, 384-394, 1989.

Sandnes, J., Forbes, T., Hansen, R., and Sandnes, B.: Influence of particle type and faunal activity on mixing of $\operatorname{di}(2-$ ethylhexyl)phthalate (DEHP) in natural sediments, Mar. Ecol.Prog. Ser., 197, 151-167, doi:10.3354/meps 197151, 2000.

Savidge, W. B. and Taghon, G. L.: Passive and active components of colonization following two types of disturbance on intertidal sandflat, J. Exp. Mar. Biol. Ecol., 115, 137-155, 1988.

Service, S. K. and Bell, S. S.: Density-influenced active dispersal of harpacticoid copepods, J. Exp. Mar. Biol. Ecol., 114, 49-62, 1987.

Slocum, E. T. and Plante, C. J.: The effect of artificial defaunation on bacterial assemblages of intertidal sediments, J. Exp. Mar. Biol. Ecol., 337, 147-158, 2006.

Snelgrove, P. V. R. and Butman, C. A.: Animal sediment relationships revisited: cause versus effect, Annu. Rev. Oceanogr. Mar. Biol., 32, 111-177, 1994.

Snelgrove, P. V. R., Grant, J., and Pilditch, C. A.: Habitat selection and adult-larvae interactions in settling larvae of softshell clam Mya arenaria, Mar. Ecol.-Prog. Ser., 182, 149-159, doi:10.3354/meps 182149, 1999.

Stocks, K. I. and Grassle, J. F.: Effects of microalgae and food limitation on the recolonization of benthic macrofauna into in situ saltmarsh-pond mesocosms, Mar. Ecol.-Prog. Ser., 221, 93-104, 2001.

Taghon, G. L. and Greene, R. R.: Effects of sediment-protein concentration on feeding and growth rates of Abarenicola pacifica Healy et Wells (Polychaeta: Arenicolidae), J. Exp. Mar. Biol. Ecol., 136, 197-216, 1990.

Thistle, D.: Nphysical disturbances and communities of marine soft bottoms, Mar. Ecol.-Prog. Ser., 6, 223-228, 1981.

Thrush, S. F. and Roper, D. S.: Merits of macrofaunal colonization of intertidal mudflats for pollution monitoring: preliminary study, J. Exp. Mar. Biol. Ecol., 116, 219-233, 1988.

Thrush, S. F., Pridmore, R. D., Hewitt, J. E., and Cummings, V. J.: Adult infauna as facilitators of colonization on intertidal sandflats, J. Exp. Mar. Biol. Ecol., 159, 253-265, 1992.

Thrush, S. F., Whitlatch, R. B., Pridmore, R. D., Hewitt, J. E., Cummings, V. J., and Wilkinson, M. R.: Scale-dependent recolonization: the role of sediment stability in a dynamic sandflat habitat, Ecology, 77, 2472-2487, 1996.

Thrush, S. F., Hewitt, J. E., Norkko, A., Nicholls, P. E., Funnell, G. A., and Ellis, J. I.: Habitat change in estuaries: predicting broadscale responses of intertidal macrofauna to sediment mud content, Mar. Ecol.-Prog. Ser., 263, 101-112, 2003.

Thrush, S. F., Hewitt, J. E., Gibbs, M., Lundquist, C., and Norkko, A.: Functional role of large organisms in intertidal communities: Community effects and ecosystem function, Ecosystems, 9, 1029-1040, 2006.
Tolhurst, T. J. and Chapman, M. G.: Spatial and temporal variation in the sediment properties of an intertidal mangrove forest: implications for sampling, J. Exp. Mar. Biol. Ecol., 317, 213-222, 2005.

Tolhurst, T. J., Black, K. S., Shayler, S. A., Mather, S., Black, I., Baker, K., and Paterson, D. M.: Measuring the in situ erosion shear stress of intertidal sediments with the Cohesive Strength Meter (CSM), Estuar. Coast. Shelf S., 49, 281-294, 1999.

Tolhurst, T. J., Gust, G., and Paterson, D. M.: The influence of an extracellular polymeric substance (EPS) on cohesive sediment stability, in: Fine Sediment Dynamics in the Marine Environment, edited by: Winterwerp, J. C. and Kranenburg, C., Proceed. Marine Sci., Elsevier Science Bv, Amsterdam, 409-425, 2002.

Tolhurst, T. J., Underwood, A. J., Perkins, R. G., and Chapman, M. G.: Content versus concentration: Effects of units on measuring the biogeochemical properties of soft sediments, Estuar. Coast. Shelf S., 63, 665-673, 2005.

Tolhurst, T. J., Defew, E. C., de Brouwer, J. F. C., Wolfstein, K., Stal, L. J., and Paterson, D. M.: Small-scale temporal and spatial variability in the erosion threshold and properties of cohesive intertidal sediments, Cont. Shelf Res., 26, 351-362, 2006a.

Tolhurst, T. J., Defew, E. C., Perkins, R. G., Sharples, A., and Paterson, D. M.: The effects of tidally-driven temporal variation on measuring intertidal cohesive sediment erosion threshold, Aquat. Ecol., 40, 521-531, 2006b.

Tolhurst, T. J., Friend, P. L., Watts, C., Wakefield, R., Black, K. S., and Paterson, D. M.: The effects of rain on the erosion threshold of intertidal cohesive sediments, Aquat. Ecol., 40, 533-541, 2006 c.

Tolhurst, T. J., Consalvey, M., and Paterson, D. M.: Changes in cohesive sediment properties associated with the growth of a diatom biofilm, Hydrobiologia, 596, 225-239, 2008a.

Tolhurst, T. J., Watts, C. W., Vardy, S., Saunders, J. E., Consalvey, M. C., and Paterson, D. M.: The effects of simulated rain on the erosion threshold and biogeochemical properties of intertidal sediments, Cont. Shelf Res., 28, 1217-1230, 2008 b.

Tolhurst, T. J., Defew, E. C., and Dye, A.: Lack of correlation between surface macrofauna, meiofauna, erosion threshold and biogeochemical properties of sediments within an intertidal mudflat and mangrove forest, Hydrobiologia, 652, 1-13, 2010.

Turner, S. J., Grant, J., Pridmore, R. D., Hewitt, J. E., Wilkinson, M. R., Hume, T. M., and Morrisey, D. J.: Bedload and water-column transport and colonization processes by post-settlement benthic macrofauna: Does infaunal density matter?, J. Exp. Mar. Biol. Ecol., 216, 51-75, 1997.

Underwood, G. J. C., Paterson, D. M., and Parkes, R. J.: The measurement of microbial carbohydrate exopolymers from intertidal sediments, Limnol. Oceanogr., 40, 1243-1253, 1995.

Van Colen, C., Montserrat, F., Vincx, M., Herman, P. M. J., Ysebaert, T., and Degraer, S.: Macrobenthic recovery from hypoxia in an estuarine tidal mudflat, Mar. Ecol.-Prog. Ser., 372, 31-42, 2008.

Vardy, S., Saunders, J. E., Tolhurst, T. J., Davies, P. A., and Paterson, D. M.: Calibration of the high-pressure cohesive strength meter (CSM), Cont. Shelf Res., 27, 1190-1199, 2007.

Watts, C. W., Tolhurst, T. J., Black, K. S., and Whitmore, A. P.: In situ measurements of erosion shear stress and geotechnical shear 
strength of the intertidal sediments of the experimental managed realignment scheme at Tollesbury, Essex, UK, Estuar. Coast. Shelf S., 58, 611-620, 2003.

Whitlatch, R. B. and Zajac, R. N.: Biotic Interactions Among Estuarine Infaunal Opportunistic Species, Mar. Ecol.-Prog. Ser., 21, 299-311, 1985.

Widdows, J., Brown, S., Brinsley, M. D., Salkeld, P. N., and Elliott, M.: Temporal changes in intertidal sediment erodability: influence of biological and climatic factors, Cont. Shelf Res., 20, 1275-1289, 2000.
Woodin, S. A., Lindsay, S. M., and Wethey, D. S.: Process-specific recruitment cues in marine sedimentary systems, Biol. Bull., 189, 9-58, 1995.

Wu, R. S. S. and Shin, P. K. S.: Sediment characteristics and colonization of soft-bottom benthos - a field manipulation experiment, Mar. Biol., 128, 475-487, 1997.

Zhou, H.: Effects of leaf litter addition on meiofaunal colonization of azoic sediments in a subtropical mangrove in Hong Kong, J. Exp. Mar. Biol. Ecol., 256, 99-121, 2001. 